This item was submitted to Loughborough's Research Repository by the author.

Items in Figshare are protected by copyright, with all rights reserved, unless otherwise indicated.

\title{
State-owned enterprises as institutional actors: a hybrid historical institutionalist and institutional work framework
}

PLEASE CITE THE PUBLISHED VERSION

https://doi.org/10.1017/mor.2021.25

\section{PUBLISHER}

Cambridge University Press (CUP)

VERSION

AM (Accepted Manuscript)

\section{PUBLISHER STATEMENT}

This article has been published in a revised form in Management and Organization Review https://doi.org/10.1017/mor.2021.25. This version is published under a Creative Commons CC-BY-NC-ND. No commercial re-distribution or re-use allowed. Derivative works cannot be distributed. (๑ The Authors.

\section{LICENCE}

CC BY-NC-ND 4.0

\section{REPOSITORY RECORD}

Butzbach, Olivier, Douglas B Fuller, Gerhard Schnyder, and Luda Svystunova. 2021. "State-owned Enterprises as Institutional Actors: A Hybrid Historical Institutionalist and Institutional Work Framework". Loughborough University. https://hdl.handle.net/2134/15060717.v1. 


\title{
STATE-OWNED ENTERPRISES AS ACTORS: AN INSTITUTIONAL WORK FRAMEWORK
}

Authors:

Olivier Butzbach

Douglas B. Fuller

Gerhard Schnyder

Liudmyla Svystunova

\author{
Affiliations: \\ University of Campania "Luigi Vanvitelli" \\ City University of Hong Kong \\ Loughborough University London \\ Loughborough University London
}

\begin{abstract}
Although state-owned enterprises (SOEs) are recognized as important economic actors, the literature to date has assumed close state control over SOEs and therefore their passive stance towards institutions. Drawing on the institutional work and historical institutionalism literatures, we challenge this view. We develop a multilevel framework of SOEs top management teams' (TMTs') embedded agency, spanning the national macro-institutional level, the meso-level of regimes of state-SOE relations, and sector-specific institutions. We then derive propositions regarding the factors across these multiple levels that shape SOE TMTs' motivation, resources, and scope for institutional work. This framework allows us to explain the leeway for and likelihood of SOE TMTs' engagement in institutional work across institutional contexts.
\end{abstract}

Keywords: state-owned enterprises (SOEs), agency, institutions, institutional work, financial repression, historical institutionalism 


\section{INTRODUCTION}

State-owned enterprises (SOEs) are considered a key tool of state control over the economy and therefore a pillar of the recent so-called "return of state capitalism" (Alami \& Dixon, 2020; Bremmer, 2008; Kurlantzick, 2016). Traditionally, this perspective assumed that the state uses SOEs as 'instruments' or 'tools' to achieve certain economic policy goals such as innovation (Bernier, 2017; Tonurist \& Karo, 2016), social and political unification, as well as promoting economic growth (Thynne, 2011). The implicit assumption is that state control over SOEs is very far reaching and SOE goals are closely aligned with state goals. More recently, however, a more nuanced view of SOE-state relationship has been emerging. Peng and colleagues (2016: acknowledge SOEs may pursue their own interests which diverge from those of their state owners. This view is in line with findings from earlier studies on SOEs, especially in the context of post-socialist transition (Markus, 2008; McDermott, 2004, 2007), whereby SOEs could explore spaces of agentic autonomy (and thereby autonomously pursue institutional change or maintenance) by either drawing on resources arising from their close relationship with the state apparatus (Okhmatovskiy, 2010), or building alliances with other stakeholders (Choudhury \& Khanna, 2014), or both. Others have gone further by arguing that SOEs have agency beyond simple autonomy from SOEs (Hafsi, 1987; Hofman, Moon \& Wu, 2017; Witt \& Redding, 2014). The kind of SOE managers' agency explored in the literature so far is primarily that driven by the need to navigate between state control and business imperatives (Rodrigues \& Dieleman, 2018). However, an emergent stream of research has turned the spotlight on SOE managers as institutional actors (Raynard, Lu \& Jing, forthcoming; Voinea \& van Kranenburg, 2018), often within the constraints of conflicting institutional logics (Guo, Huy and Xiao, 2017; Jing \& McDermott, 2013).

In this paper we extend this conversation on SOE TMTs as institutional actors and argue that SOE top managers are not just agents of the state but are actively engaged in either changing 
or maintaining the institutional setting within which SOEs operate. Due to their inherent political nature, we argue that their role may be particularly important regarding their influence over the country's institutional environment. Specifically, we focus on the factors, institutional and otherwise, which determine SOEs' institutional work (IW), which we conceive here as purposeful action geared towards maintaining or altering SOEs' institutional environment (Lawrence, Suddaby \& Leca, 2011). Our main research question is therefore: What factors determine SOE TMTs' motivation and leeway to pursue IW?

To answer this question, we draw on two literatures: the literature on IW, mentioned above; and the historical institutionalist (HI) literature, which has developed as an original and fruitful approach to the issue of embedded agency which is key to understanding SOEs' institutional agency. Indeed, we conceive SOEs as purposive and boundedly rational agents that are embedded in an institutional environment that shapes both their motives to act on it and their capability to do so. This is an important premise in the HI literature on institutional change (Thelen, 2004; Pierson, 2004; Mahoney and Thelen, 2010), whereby even institutional maintenance requires purposeful action. These two literatures usefully complement each other in the understanding of the issue. Indeed, while we use a more micro-level IW perspective to complement HI's broader, more macro-level understanding of embedded agency at the heart of processes of institutional change and persistence, we also draw on HI's political economic conceptualization of institutional dynamics to compensate for the limitations of IW. In particular, this paper fully recognizes the importance of the political factors characterizing SOEs' institutional environment. Thus, we contribute both to the understanding of SOEs' agency, on the one hand, and to the theorization of institutional change in both IW and HI literatures.

In this paper, we define SOEs as any commercial enterprise that is either part of the state bureaucracy or that is a legally independent unit, but whose shares are to a significant degree 
owned by the state or its agencies. Such ownership can range from full to a minority stake held by the state. We do not include in our definition companies where the state influences private companies through means other than ownership - e.g., through heavily subsidized loans or regulation and governance mechanisms such as 'golden shares' - to achieve certain political goals (Fuller, 2016; Musacchio et al., 2015). With increasing numbers of SOEs that are not fully state-owned, scholars recognize that the relationship between state and SOEs is far from straightforward. Indeed, the state is often not the only shareholder in SOEs (Rodrigues \& Dieleman, 2018). When SOEs are only partly state-owned and listed on a stock exchange, minority shareholders may have considerable rights that give them some influence over SOE decisions (Musacchio et al., 2015). Such complex ownership structure may weaken the direct influence the state has over SOEs and provide SOE top management teams (TMTs) with more autonomy from the state than the 'SOEs as tool' view would allow (Stark \& Vedres, 2012; Markus, 2008, 2012).

Furthermore, states differ in terms of the vehicles they use to manage their shareholdings in SOEs. In some countries, state ownership is directly managed through ministries. In others, the state sets up an investment fund, or uses a public pension fund to do so. Finally, with time some SOEs might choose to pursue a stronger focus on commercial goals despite the persistent scrutiny from the government (Guo, Huy \& Xiao, 2017). Even in settings where SOEs are wholly owned by the state and the state plays a very dominant role - such as in state-socialist Europe before 1989 - SOE managers have leeway to pursue their own goals (Stark \& Bruszt, 2001). These goals may or may not be aligned with state goals and may lead SOE TMTs to actively seek to shape the institutional environment in which their enterprises operate in order to achieve these goals. In this paper, we focus on the institutional arrangements of state ownership that shape the motivation, resources and scope for SOE TMTs to engage in institutional work (IW) (Lawrence, Suddaby \& Leca, 2011) in pursuit of their goals. 
In this paper, we develop a theoretical framework that allows us to conceive of SOEs top management teams as institutional actors positioned in a multi-layered institutional environment that serves as a source of strategic resources and constraints for agency. We then consider how institutional factors shape motivation, scope and resources for SOE TMTs' IW ${ }^{[1]}$, formulating testable propositions. To illustrate our arguments, we draw on examples from emerging economies, where SOEs have been major players in both the economic and the political arena and where SOE TMTs have the potential to contribute to the shaping of local institutions (Yan, Zhu, Fan \& Kalfadellis, 2018), and from developed economies, where SOEs have been a staple of past development and may still represent significant sources of IW.

The paper is organized as follows: Section 2 discusses the theoretical foundations of our framework, which is presented in detail in Section 3; Section 4 discusses the wider theoretical contributions of our approach as well as its limitations.

\section{THEORETICAL BACKGROUND: A MULTI-LEVEL INSTITUTIONAL WORK PERSPECTIVE ON SOE AGENCY}

The extant literature does not provide us with adequate theoretical tools to understand the increasing variety of SOEs, the variety of their relationships with the state and, especially, SOEs' various strategies and actions geared towards maintaining or altering their institutional environment. To fill this gap, we use the concept of institutional work (IW), developed within an emerging literature (Lawrence \& Suddaby, 2006; Lawrence et al., 2009; McGaughey, Kumaraswamy \& Liesch, 2016). We also draw on previous literature on bottom-up institutionbuilding by firms (in particular in the post-socialist transformation context) to develop a 
theoretical framework of how SOEs attempt to shape their institutional environment and alter their relationships with the state (McDermott, 2007; Stark and Bruszt, 2001).

IW encompasses the purposeful actions of individuals and organizations aimed at maintaining, creating, and/or disrupting institutions, the "(more or less) enduring elements of social life that affect the behavior and beliefs of individuals and collective actors by providing templates for action, cognition, and emotion, nonconformity with which is associated with some kind of costs" (Lawrence et al., 2011, p. 53). IW is therefore akin to the concept of institutional entrepreneurship (Willmott 2010; Leca \& Naccache, 2006; Garud et al., 2007) that seeks to understand the 'paradox of embedded agency,' namely that according to neo-institutional theory, actors behave in isomorphic ways, but nevertheless maintain the ability to bring about institutional change endogenously (Garud et al., 2007). However, beyond institutional entrepreneurship which it encompasses (Tracey et al., 2011), IW adds three nuances. Firstly, IW includes types of actions that lead to not only radical but also incremental institutional change (Liu et al., 2016). Secondly, it acknowledges the cumulative and quotidian nature of institution-building by actors who are embedded in the institutional fabric (Lawrence et al., 2011). Indeed, unlike path-breaking focus of institutional entrepreneurship and attempts to change formal institutions - the domain of the corporate political activity (CPA) literature (Mizruchi, 1992; Mellahi et al., 2016) - IW is broader and also includes actions that take place outside of formal channels (Lawrence et al., 2009). Thirdly, this also implies, that while purposive, IW is not always directly targeted at institutions, but can affect institutional change or maintenance as byproduct of broader behaviors and actions. We prefer the concept of IW to other concepts, because it allows for a broader understanding of the manifold and complex interactions between actors and institutions and bridges critical and institutional views of organizations. 
Within the IW literature, considerable attention has been paid to the interactions of actors with authorities and particularly the state apparatus. For instance, Micelotta and Washington (2013) examined how Italian legal professionals curbed government attempts to introduce a reform that would have disrupted the profession. Yan and colleagues (2018) theorized IW in the context of internationalizing Chinese firms and how their interactions with the state co-produce the policy environment for outward foreign direct investment (OFDI).

Crucial to the concept of IW is the notion of intentionality (Battilana \& D'Aunno, 2009). Although intentionality is seemingly at odds with the tenets of institutional theory such as stability and embeddedness, IW sees agency as "an ongoing activity whereby actors reflect on and strategically operate within the institutional context where they are embedded" (Lawrence et al., 2011: 55). Hence, intentionality can take the form of habitual enactment of taken-forgranted schemas, or a more conscious and strategic future-oriented reshaping of extant institutions, but equally a pragmatic response to the environmental forces (Emirbayer \& Mische, 1998; Battilana \& D’Aunno, 2009). In other words, institutions are not always the intended object of agency, but actors may, inadvertently or not, shape institutions while seeking to reach other objectives (Smets \& Jarzabkowski, 2013).

SOEs are generally considered to be highly institutionally embedded. As such, they may benefit from heightened political legitimacy (Li \& Zhang, 2007; Marquis \& Qian, 2013). Their actions are likely to have political consequences and may be expected, in many cases, to be supportive of government policies and ideology (Hofman, Moon \& Wu, 2017), whether these policies aim at altering or reinforcing the existing institutional environment. However, in periods of “institutional transition" and "liberalization" (Peng, 2003), SOEs' clout and legitimacy may be challenged, which may lead them to oppose policies of pro-reform governments. In such a context, SOEs would tend to be a conservative force and pursue conservative strategies of institutional order maintenance (Micelotta \& Washington, 2013). These stances - opposing or 
supporting institutional change - can be held by SOEs irrespective of the goals of the state. Whether or not their goals align with state goals in specific cases, SOE top management teams may be driven to use their political resources as leverage to reach their goals related to their institutional environment. ${ }^{[2]}$

In yet other cases, SOEs TMT may also resent the institutional status quo for a variety of reasons (which will be spelled out below) and thus seek to actively change their institutional environment. In particular, SOEs may seek to perform IW to counterbalance the potential constraints arising out of their close ties with the state. This has been particularly evident in the research on SOE internationalization, which traditionally started with the assumption of SOEs as "captives of the state" (Rudy, Miller \& Wang, 2016: 76). This logic dictates that SOEs internationalize to benefit their home country and are largely guided by political, rather than managerial objectives. However, an emergent "power escape" perspective (Cuervo-Cazurra et al., 2014; Rodrigues \& Dieleman, 2018) challenges these assumptions and shows that internationalization can be a means to escape the confines of state ownership by reducing resource dependence on the government. Alternatively, internationalization can serve as a precursor to recognizing the need for power escape in the first place. Rodrigues and Dieleman (2018: 40) cite the example of Malaysia's Petronas whose "top management was quoted as saying they regretted being the government's number one 'piggy bank' as they would rather invest in continued globalization."

Understanding SOEs' engagement in IW requires considering the multi-layered institutional environment they face - both as a target of IW and its determinant. The notion, implied by the expression of "institutional environment", of institutions as external to the firm may be debatable in the case of SOEs (even more than in the case of private firms; see Bitektine et al., 2020; Battilana \& D'Aunno, 2009), given that institutions are often constitutive of SOEs themselves - and the understanding that institutions can emerge through organizational 
strategies (Lawrence and Suddaby, 2006). Accordingly, the literature has increasingly treated SOEs as hybrid organizations (Bruton et al., 2015; Peng et al., 2016), characterized by their multiple bottom lines, that is, the fact that they contemporaneously pursue financial or business goals and social, political, or environmental goals (Musacchio et al., 2015). The hybridity of SOEs implies the porousness of the boundaries between "the state" and non-state entities. Such porousness is also more broadly implied by the variety of governance arrangements characterizing state-firm relations, explored inter alia by Musacchio and colleagues (2015), suggesting, rather than a sharp dichotomy between the state and private firms, a more nuanced continuum, and, consequently, a variety of degrees to which SOEs are exposed to business and state institutional logics (Rodrigues \& Dieleman, 2018; for institutional logics, see Thornton, Ocasio \& Lounsbury, 2012).

For these reasons, more than privately-owned firms, SOEs face the "paradox of embedded agency" (Seo \& Creed, 2002): SOEs are simultaneously constrained by their institutional environment while actively involved in trying to affect that environment. There are different ways to address this paradox. The IW literature deals with it upfront (Lawrence et al., 2011) by acknowledging the various dimensions along which IW may take place and the various levels where institutions may influence agency. Battilana and D'Aunno (2009), for example, distinguish between field-level, organization-level and individual-level conditions for IW. Our framework builds on these foundations but supplements it with a more macro-level focus (Hwang \& Colyvas, 2011), by unpacking the multi-layered institutional environment in which SOEs operate and differentiating the degrees of agency associated with each layer or component. Specifically, we identify three main layers of SOEs' institutional environment: (i) the national institutional level; (ii) the regime of state-SOEs relations (governance system); (iii) sector-specific or market-level institutions. Each one of these three levels of SOEs' institutional 
embedding can become the target of SOE IW, but at the same time also correspond to particular sets of resources and constraints that determine SOE IW.

The degree and nature of IW may vary across these different layers. For instance, sector-specific rules and regulations are typically the target of corporate political activity as a particular category of IW (see Lawton, Rajwani \& Doh, 2013), such as lobbying to maintain existing entry barriers that favor the firm (Oliver \& Holzinger, 2008), influencing public agencies to obtain favorable regulation, or adhering to government signals to obtain political legitimacy and avoid radical regulatory change (Marquis \& Qian, 2013; Guo et al., 2017). By contrast, higher-level institutions are less amenable to such direct non-market strategies. Here, individual SOEs may be encouraged to seek to build broader coalitions with actors within and outside the state apparatus. The level of the state-SOE governance system, on the other hand, may exercise mainly a moderating effect on the extent to which SOEs are able to exercise IW.

Given the multiplicity of layers that constitute SOEs' institutional environment, we may expect across- as well as within-country variation in the institutional determinants of SOEs' IW. Thus, our attempt to theorize SOE IW is necessarily a multi-level enterprise - involving the investigation of the interaction between firms' characteristics, strategic behavior, and institutional environment at various levels.

Our additional focus on the macro-level determinants of SOEs' institutional work enables us to fully consider the political factors underpinning institutional change, as emphasized in the historical institutionalism (HI) literature (Thelen, 2004; Pierson, 2004; Streeck and Thelen, 2005; Mahoney and Thelen, 2010). Indeed, institutions are "the object of ongoing political contestation", and thus "political dynamics [...] drive institutional genesis, reproduction, and change." (Thelen, 2004, p.31) In particular, political factors partly determine the coalitional foundations of institutions (Thelen, 2004; Mahoney \& Thelen, 2004). Our framework further 
draws on HI by conceiving SOEs' agency as distinct both from the "actor-centered functionalism" (Pierson, 2004) that may be nested in institutional entrepreneurship, and the complete absence of agency implied by structuralist accounts of institutional stasis (Thelen, 2004; Mahoney and Thelen, 2010). As Hall puts it, “[a]cknowledging [institutions'] plasticity raises questions about when institutions should be seen as determinants of behavior and when as objects of strategic action themselves." (Hall, 2010, p.204)

$\mathrm{HI}$ is equally useful in helping us think about institutional change and maintenance, the outcomes of SOEs' institutional work, as causally equivalent, that is, resulting from similar processes. In other words, as shown by Thelen (2004) and Pierson (2004), institutional stasis does not simply result from mechanistic processes of self-reinforcement, or positive feedbacks. Thelen argues that institutional survival often entails both institutional adaptation and transformation so these "inherited" institutions better fit with current political, social and economic trends (Thelen, 2004, p.293). Vice versa, institutional change should not be expected to automatically "emerge from actors with transformational motives." (Mahoney and Thelen, 2010, p.22). In fact, Streeck and Thelen (2005) and especially Mahoney and Thelen (2010) have precisely re-framed institutional persistence and change as different modes of institutional change, seen as a continuum. In turn, these different modes of change are brought about by different types of "change agents" - the latter forming "the intervening step through which the character of institutional rules and political context do their causal work" (Mahoney and Thelen, 2010, p.28).

This is where our own framework, while building on the broad foundations laid out by HI, diverges from the specific theory of institutional change proposed by Mahoney and Thelen (2010). Indeed, for us the question of outcome and directionality (of institutional change) needs to remain an empirical question. Attempts to theorise directionality in the literature remain - in our view - unconvincing. Thelen \& Mahony (2010) propose a theorisation of directionality by 
making strong assumptions about situations of institutional changes being struggles over status quo. Such attempts at theorising change contradict some fundamental assumptions on which HI is otherwise based (e.g. Streeck \& Thelen, 2005, on continuity and change through embedded agency; see also Zara \& Delacour, 2020).

Mostly, however, our divergence with $\mathrm{HI}$ accounts of institutional change is rooted in a different analytical focus: while the analysis of Mahoney and Thelen (2010) is mostly an analysis of processes that cause certain types of institutional change, we are focusing on the determinants of SOE agency, which may equally drive SOEs to pursue institutional work (and thus institutional change or persistence) or not. Our analytical framework is a more "upstream" investigation into the relationship between the institutional environment and SOEs' impetus to pursue change, while Mahoney and Thelen's framework is a "downstream" analysis of the "affinity between particular kinds of actors and modes of change" (Mahoney \& Thelen, 2010, p.27).

The next section builds on these theoretical foundations to develop a full, multi-level framework to understand the determinants of SOEs' institutional work.

\section{Understanding the determinants of SOEs' IW: Towards an encompassing framework}

\subsection{Resources, motivation, and scope of IW}

Our conceptual framework is premised on the notion that in order for an $\mathrm{SOE}^{[3]}$ to be able to engage in IW, it requires three necessary elements. Each one of these are shaped by determinants situated at one of the three levels of SOEs' institutional environment described above. More specifically, the three elements can be defined as 1) SOEs' capacity to perform IW by mobilizing the required resources $^{[4]}$; 2) SOEs' reasons and willingness to take action to change or maintain their institutional environment, which in turn derives from the congruence 
- or lack thereof - between SOE TMT goals and the institutional framework (motivation for IW); 3) the nature and extent of constraints on SOEs' IW stemming from its embedding in a specific state-SOE governance system, which - in combination with the resources available to SOEs - may increase or reduce the opportunities for SOEs to perform IW (scope for IW). We will discuss these three factors - summarized in Figure 1 - before moving on to identifying their main determinants and formulate theoretical propositions by drawing on illustrative examples from developed and emerging markets.

It is important to be explicit about the key assumption of our framework, i.e., that the main locus of SOE agency is their TMTs. This assumption is, in line with the economic literatures on managerial discretion (Williamson, 1963) and agency theory (Jensen \& Meckling, 1976) that hint at potential conflicts of interest between SOE's TMT and the state as a shareholder. However, it is less consistent with sociological approaches to the firm, which hint at the role that actors at all levels of the organization play in the core studies in the IW perspective. Within an SOE context, actors other than the firm's TMT might be politically important and as wellconnected to parts of the state apparatus and/or policy-making bodies as TMTs. For instance, unions and union members might be on the front lines of IW in certain contexts (Pandey \& Varkkey, 2020). Such IW certainly deserves to be considered. However, SOEs' IW presents characteristics that support our choice to focus on TMT's agency. First, SOEs are mostly sizeable, established organizations with, in many instances, a past of being a state bureaucracy - and when not, the experience of being tied to state bureaucracy through ownership and other ties. This makes it reasonable to expect politically sensitive IW to be performed by top managers. Secondly, the more macro layers of SOEs' institutional environment lend themselves less to the micro-oriented practice and boundary work IW scholars have in mind when analyzing actors' agency (cf. Zietsma \& Lawrence, 2010). 


\subsubsection{Resources}

SOEs' ability to perform IW will be determined by the nature and the amount of resources they will be able to draw on (Battilana, Leca \& Boxenbaum, 2009). The literature distinguishes different types of resources on which SOEs may draw when carrying out IW, including financial resources, organizational resources allowing them to influence political choices (e.g. PR expertise), and political resources, such as their ties with policy-makers at various levels (regulatory agency, law-making body, state shareholding managing body) (Boddewyn, 1994; Bonardi, 2011; Schnyder \& Sallai, 2020). ${ }^{[5]}$ The availability of these resources is related to firm-level characteristics - in particular, firm size and strategic value.

Size matters because of the financial resources associated with it, and thus the financial capacity to perform costly non-market activities such as lobbying. ${ }^{[6]}$ Moreover, bigger SOEs have a greater political clout; they are affecting a larger number of people and, consequently, a larger number of politicians' constituents (see Salamon \& Siegfried, 1977). Political clout leads to more political resources (e.g., direct access to high-ranking public officials).

Strategic value, on the other hand, captures how much importance the state places on a sector or industry where any given SOE is active in. Such importance may be associated with national security reasons, reasons linked to regime survival, to economic development/wealth generation or broader social priorities (Hsueh, 2016). Commonly, states at a minimum regard defense and energy sectors as having strategic value. Strategic value can be a substitute for size: SOEs that operate in strategic industries such as defense, energy, or telecommunications, regardless of their size, will have more political clout as well. SOEs that are deemed as "national champions" correspond to these characteristics (Thun, 2004).

\subsubsection{Scope}


A second factor that influences SOE IW is scope, which we define here as the ability and leeway of any given SOE to engage in IW as determined by its resources and embeddedness in the governance system. Scope relates both to the extent to which the state-SOE governance system provides channels for IW and to the nature of these channels. While motivation and resources are firm-level features, scope - while partly determined by SOE resources - also reflects the state-SOE governance system more broadly. SOEs' political resources influence scope for IW e.g. by providing channels for IW through political connections - a key political resource. Yet, regardless of resources, SOEs scope to perform IW can still be constrained/enabled by the range of actions made available by the configuration (i.e., the nature and extent) of the state-SOE governance system. We understand the state-SOE governance system as the system of rules, regulations and institutions that govern the relationships between the state as owner and SOEs in any given country. While we conceive scope as determining SOEs' capacity to engage into IW, regardless of SOE TMT's motivation to do so, we also hold scope to influence motivation for undertaking IW in the first place. Indeed, perceived opportunities for meaningful action may induce agents to act on their goals. Thus, the relationship between scope for IW and motivation for undertaking IW closely mirrors the relationship between perceived opportunities and institutional agency as conceptualized by Dorado within an "institutional entrepreneurship" context (Dorado, 2005).

\subsubsection{Motivation and goals}

Finally, the likelihood of IW is strongly determined by SOE TMT's motivation to perform IW. The latter derives from both perceived opportunities for effective IW and from the likely effects of (desired or envisioned) institutional change on SOEs' position, and how that affects - in turn 
- the TMT interests or values. To understand SOE TMT motivation to perform IW, we therefore need to understand what these interests and values are.

Our framework is based on a model of action where economic behaviors can be driven either by striving for satisfaction of material interests or behavior that follows 'shared scripts' derived from social norms and values. Action is purposive, but not necessarily rational, self-seeking, and maximizing. To accommodate this multidimensionality of human action, we therefore prefer talking about "goals" rather than interests or values. The notion of "goal" allows us to capture a desired outcome that a social actor pursues - be it a collective actor (state, government), or and individual (SOE manager) - without making any a priori assumptions about the underlying driver of the action. The key question is not whether TMTs behave out of selfishness or belief in some public good, but rather whether the goals that they pursue are aligned or not with those of the state and the institutional framework.

The SOE literature derives the goals that the state, SOEs, and SOE managers pursue in two different ways. One is to theoretically derive them from existing theories of the firm (Peng et al., 2016); the second one is to infer them from empirically studies of SOE motivations to undertake certain business activities, e.g. acquiring other firms (Florio et al., 2018), or from historical cases (Cuervo-Cazurra, Inkpen, Musacchio, \& Ramaswamy, 2014). Combining these approaches, we identify five broad goals that SOEs and their managers pursue: commercial goals, strategic policy goals, welfare goals, political goals, and TMT's private goals (see Table 1 below). Importantly, these categories of goals are not mutually exclusive, but any given SOE action may fulfil different types of goals at once.

The traditional view of SOEs starts from the point of view of the state (or government) and seeks to answer the question 'why do states establish SOEs?' From a purely commercial point of view, the income generated by an SOEs commercial activity may be reason enough for the 
state to own firms (see Table 1 'supra-organizational commercial goals'). Yet, beyond such commercial goals, a key argument refers to market failures or imperfections. On this account, governments establish SOEs or take ownership stakes in firms when markets or private firms are unable to efficiently allocate resources (Cuervo-Cazurra et al., 2014) or to produce goods and services that are instrumental for social welfare. Such goals can hence either fall into the categories of 'welfare goals' (when the goal is to provide a social service to citizens as individuals) or 'strategic policy goals' (e.g., providing people and businesses in a country with access to electricity).

Other historical reasons for state ownership of SOEs are ideological, e.g., referring to nationalist, socialist, or developmentalist ideologies, which consider state control of critical resources as essential. Such ideological reasons mostly fall within the category of 'strategic policy goals.' Other strategic policy goals derive from economic theories that see stateownership as an important tool for national economic development, e.g., through import substitution strategies or other industrial policies that target specific strategically important sectors (Cuervo-Cazurra et al. 2014).

The "SOEs-as-policy-tool view" assumes that these collective goals the government pursues in establishing SOEs will be closely reflected in SOE motivation and behavior. In particular, if the state's reason for owning companies is to pursue strategic and macro-economic goals, we would expect these to be key motivations of SOE managers.

However, as we have argued above, this is too narrow a view. Even if we accept the instrumental view of SOEs as tools of the state, in reality, state goals tend to go beyond economic considerations. Indeed, theories of SOEs have pointed out the multi-dimensional nature of goals that SOEs may pursue. Thus, Peng and colleagues (2016: 299; Table 2) summarize the goal of SOEs as finding the "[o]ptimal balance for a "fair" deal for all 
stakeholders. Maximizing profits is not the sole objective of the firm. Protecting jobs and minimizing social unrest are legitimate goals."

We classify goals such as 'protecting jobs' or 'minimizing social unrest' as welfare goals and strategic policy goals respectively. The simultaneous presence of 'commercial interests' (such as pursuing profit maximization, market share, or shareholder value for their company), 'societal' interests (e.g. reducing unemployment), and political interests (e.g. providing jobs for certain politicians' constituencies) is seen by many authors as one of the key reasons for alleged financial underperformance of SOEs compared to privately owned companies (Megginson \& Netter, 2001; Shleifer \& Vishny, 1998).

While these studies shed some light on motivations that SOEs may pursue, they do not inform us about the motivations of SOE managers themselves. Indeed, these approaches assume that governments' - and hence SOEs' - main motivation is one of pursuing collective interests, be they commercial, strategic, or social. Yet, the contention of this paper is precisely that SOE managers' goals and the goals of the state may or may not be aligned. Agency theory, for instance, states that rather than pursuing any collective state goals, SOE managers will seek to maximize their own private benefits (Lazzarini et al. 2020; Peng et al., 2016; Musacchio et al., 2012). On this account, SOE managers will not pursue societal or commercial goals, but rather purely private interests such as career advancement, on the job consumption, or high remuneration (Cuervo-Cazurra et al., 2014).

Applying this agency theory reasoning not just to SOE TMTs, but also to politicians, a further category of goals emerges, namely political goals. Indeed, while the first categories of commercial, strategic, and welfare goals are largely collective in nature, agency theory would suggest that politicians may not be interested in achieving collective goals unless they are instrumental in securing their own personal goals, most importantly conservation of power. In 
a democracy, this will most likely be achieved through re-election which creates incentives for politicians to provide rents to key constituencies, e.g., through (over-)investment in certain geographical areas. But even in no-democratic systems, using SOEs to generate rents for citizens can contribute to regime legitimacy and stability and hence be in politicians' individual self-interest.

Depending on the SOE TMTs' perceived goals, politicians pursuing personal goals may create reasons for SOE TMTs to seek autonomy from the state bureaucracy. For instance, when politicians seek to use SOEs as a means to guarantee reelection or regime legitimacy, but TMTs are committed to SOEs' commercial goals, pursuing a strategy of increased autonomy from the state may become a key goal for SOE TMTs. Conversely, SOE TMTs that pursue self-seeking goals may seek autonomy from a collectively orientated state to escape close monitoring and obtain more leeway in generating private benefits of control.

Yet, extant literature is ambiguous about SOE managers' pursuit of autonomy. The resource dependency theory would lead to the prediction that SOEs (and SOE TMTs) seek to strengthen their political ties with the state bureaucracy to secure crucial resources and to enhance "the mutual dependency between these SOEs and officials" (Peng et al., 2016: 309). A preference for close ties with the state, can also be derived from agency theory when close ties with politicians can be considered to be conducive to SOE managers' career advancement

However, both agency and resource-dependence theories construe managers' interests, and hence goals, rather narrowly. Managers may, of course, be driven by their material self-interest, but also by norms and values. This was, indeed, the object of the managerial discretion literature since the 1960s. Once these assumptions are broadened to accommodate equally valid motivations such as trust or loyalty (see the essays in Gintis et al., 2005), agency theory may be replaced with other frameworks, such as stakeholder theory (Shankman, 1999). The 
conception of the manager as a self-interest-seeking individual is further eroded when considering broader organizational values managers might identify with. In particular, top managers (as other organizational actors) might be interested in the survival and success of their organization, as the literature on "organizational citizenship behavior" has shown (see Smith et al., 1983; Bolino \& Turnley, 2003). In the cases where such behavior can be observed, employees of an organization display a disposition to "subordinate their individual interests for the good of the organization, and to take a genuine interest in its activities and overall mission" (Bolino \& Turnley, 2003, p.61). The "good of the organization", moreover, may be identified with broader social welfare; there is some evidence that managers play a leading role in driving their firms' corporate social responsibility efforts (Swanson, 2008).

Moreover, and closer to our argument, the hybrid nature of SOEs (their dual or multiple bottom lines) may imbue their top management teams with the equivalent of a "public service ethos" found in civil service organizations (Horton, 2006; Van der Wal et al., 2008), which might be tied to organizational citizenship behavior, (see Rayner et al., 2012). The degree to which TMTs adhere to such ethos depends on the type and origins of SOEs, which may vary significantly, as we have previously noted. However, we may expect that similar principles still drive the conduct of top management in certain SOEs and/or countries.

Furthermore, the goals of SOEs' managers might be driven by something akin to class interest, which may or may not align their goals with the state bureaucrats managing state shareholdings in SOEs, or the senior staff in regulatory agencies. This "class-wide rationality" of corporate elites has attracted some scholarly attention in the past (e.g., Useem, 1982). Given the persistent common social origins and educational background of corporate elites and top state bureaucrats in countries such as France, we may expect these common class interests to survive in some contexts 
Alternatively, SOE TMTs may have formed, or may express the functioning of, sociopolitical networks involving state bureaucrats as well (McDermott, 2004). Beyond the material or immaterial interests of individual managers, the existence of such networks may induce top managers to behave in a way that conforms to those networks' collective interests or norms (Windolf, 2002). In addition, membership in such networks may have framing effects, i.e., it might help managers to frame their interests in a way that is consistent with their expectations of what their peers / other network members see as valuable.

This ambiguity hints at a more fundamental point, namely that different, seemingly incompatible SOE and SOE TMT goals may be contingent on firm-level, sector-level, or national-level factors. This can also be illustrated by the changes in SOE preferences over time. Recent empirical studies have found based on international evidence on SOE's merger and acquisition (M\&A behavior) that a vast majority (60\%) of acquisitions undertaken by SOEs were motivated by commercial goals that are related to shareholder value maximization (Florio et al., 2018). Strategic motivations - such as the development of strategic sectors (e.g., renewable energies) and control of key natural resources - as well as welfare goals - such as bailing out firms in financial distress - are secondary motivations (Florio et al., 2018: 144). Florio and colleagues (2018) interpret this as the result of a shift of "modern" state capitalism towards a higher importance of commercial goals compared to welfare or political goals which dominated earlier forms of state-dominated economic systems.

Based on this categorization of SOE (and) TMT goals, our framework suggests that SOE TMTs' motivation to perform IW will depend on whether SOE TMTs' perceive potential advantages in achieving their goals by promoting/opposing institutional change or stability. We focus on institutional change because we assume here that IW is essentially geared to either spur institutional change, when SOE TMTs (believe to) increase their ability to achieve their goals by changing the rules of the game - for instance, by supporting a government's proposed 
reform; or to favor institutional maintenance, when, on the contrary, SOE TMTs perceive changes in the rules of the game to lead to a decreased ability to achieve their goals. As such, SOE TMTs' motivation to pursue IW will depend on two aspects: the goal configuration at hand in any given context, and the way in which TMTs evaluate the congruence of their goals with the existing institutional framework or proposed changes thereto. Therefore, the IW approach complements the agency view, in the sense that the opposition of SOE TMT and state interests is just one special case among a series of possible configurations.

As explained above different sub-goas should not be seen as exclusively associated with one higher-order goal. Thus, reducing unemployment can be a strategic policy, a welfare as well as a political goal. Similarly, any given action may allow actors to achieve several goals at once. Motivation for IW, on the other hand, results from the interaction of goals and institutions and various levels. Table 1 below summarises these key goals.

\section{[INSERT TABLE 1 ABOUT HERE]}

Figure 1 summarizes our causal model to explain the possibility of the occurrence of SOE IW.

\section{[INSERT FIGURE 1 ABOUT HERE]}

Next, we identify the key factors that determine the motivation, resources, and scope of IW by SOEs.

\subsection{The determinants of SOE TMTs' IW}

We identify eight factors, situated at three different levels, affecting SOE TMTs' IW: At the macro level, financial repression and industrial policy are key elements of a national institutional environment that influence SOE TMTs' IW. At the level of the state-SOE governance system, the key determinants are the nature and structure of state-SOEs relations in 
terms of the number (fragmentation) of formal lines of authority, the degree of state ownership, the embedding of SOE top managers in the political system or the nomenklatura, and the autonomy of the state shareholding authority from the government. At the industry level, the extent to which a sector is characterized by vertical integration and the place of technical change are key determinants. We discuss these determinants in turn and formulate propositions.

\subsubsection{National macro-level institutions}

\subsubsection{Financial repression}

Financial repression consists of policies that "keep nominal interest rates lower than would otherwise prevail" (Reinhart, 2012). ${ }^{[7]}$ Thus financial repression typically features controls over interest rates on both bank deposits and loans with spreads substantial enough to keep the banks viable while the interest rates are set below market value (Park \& Patrick, 2013; Pettis, 2013). ${ }^{[8]}$ Governments have historically used financial repression to encourage investment in those sectors they prioritize. Several emerging and industrializing economies have undertaken financial repression to foster economic and industrial development: from Nazi Germany (Tooze, 2006) to the Northeast Asian industrializers of Japan, Korea and Taiwan during their $20^{\text {th }}$ century boom (Patrick \& Park, 1994) to China today (Park \& Patrick, 2013; Pettis, 2013).

Where it exists, financial repression can be a key feature of SOEs' macro institutional environment, determining both the motivation for SOEs' IW and the nature and amount of resources SOEs may draw upon to engage in IW. For instance, China has not only had some of the strongest financial repression (measured in terms of the transfer of wealth from household savers to industrial investors as a percentage of GDP) in history (Pettis, 2013), but in contrast to countries such as Korea and Japan, China, due to its Leninist party-state, has prioritized SOEs as the targets of cheap loans for industrial investment. Top managers at SOEs have been able to utilize financial repression to entrench themselves in the Chinese economy. Financial 
repression has provided China's SOE top managers with the financial wherewithal to empire build. The key is to become large enough to achieve too-big-to-fail status in the eyes of the state leadership and the cheap capital provided by financial repression helps SOEs do just that (Fuller, 2016; Huang, 2003, 2008; McMahon, 2018; Pettis, 2013).

Moreover, financial repression combined with the use of state-owned commercial banks whose lending is guided towards state-privileged SOEs, often at very advantageous conditions such as the absence of a requirement for collaterals (O'Connor, 2000), provides SOEs with a further lever over government, namely Non-Performing Loans (NPLs). Indeed, in countries like China and Vietnam, the loans taken out by SOEs can acquire a systemic importance that locks the government into a mutual-hostage situation making it difficult to reform SOEs, and thus securing the latter's privileged position in the financial system (cf. O’Connor, 2000).

In this context, Chinese SOEs strategically strive to enhance mutual dependence between themselves and the state (Peng et al., 2016: 309-310). ${ }^{[9]}$ This behavior can be interpreted as a case of IW by SOEs, which has resulted in institutional maintenance (in this case, the maintenance of the system of SOE-oriented financial repression) promoted by the SOEs themselves. Since the announcement of major reforms to end the system of financial repression and concomitant lending bias towards SOEs at the Third Plenum of the $18^{\text {th }}$ CPC Central Committee in November 2013, top leaders, such as Premier Li Keqiang, have often alluded to interest groups including SOEs as blocking these economic reforms (Fuller, 2016; Minzer, 2018; McMahon, 2018). Indeed, one of the major optimists who earlier interpreted Chinese financial data as heralding the burgeoning of its private economy in place of the SOEs, Nicholas Lardy (2014), has recently admitted that the financial system continues to be heavily biased towards supporting SOEs and points out that loans to private firms have collapsed since 2012 whereas the share of loans going to SOEs has tripled. ${ }^{[10]}$ 
In juxtaposition to the maximalist Chinese case of high financial repression with the cheap credit of that repression being directed to SOEs, the Taiwanese minimalist case of financial repression allows us to understand under what conditions financial repression increases resources and motivations for SOEs to engage in IW. Taiwan pursued financial repression from the 1950s into the 1980s (Patrick \& Park, 1994). However, its financial repression was much lighter (less credit shifted from households to firms and at less generous interest rates) than what occurred in Korea, Japan and China (Park \& Patrick, 2011; Pettis, 2013) and less directed to SOEs in preference other firms (Fields, 1995; Patrick \& Park, 1994).

Yet, the prominence of state ownership in Taiwan's economy was quite pronounced. Stateowned firms comprised almost half (49\%) of manufacturing value-added in 1951. Even as private enterprise boomed and the public share of manufacturing value-added slipped below twenty percent by 1976, the state in the 1970s was still investing in large SOEs in shipbuilding, steel, petrochemicals, autos and semiconductors (Hsueh et al., 2001; Chu, 2017).

Despite their former prominence, by the late 1980s, the state had managed to remove SOEs from a leading role in most of these sectors. Even the most ambitious and successful of the SOEs to emerge from the heavy industrialization push of the 1970s, China Steel, was unable to prevent the liberalization of the steel trade and failed in its bid to consolidate Taiwan's private minimills under its ownership. Instead, the firm faced new private competitors (Noble, 1998). Similarly, in the mid-1980s, private mid-stream petrochemical producers were allowed to invest in their own upstream, naphtha cracker plant in competition with state monopoly producer, China Petroleum Corporation (Hsueh et al., 2001).

The main reason the Taiwanese SOEs were not able to engage in effective IW to block privatization even though many of them tried to do so (Hsueh et al., 2001; Noble, 1998) was the nature of the financial repression in Taiwan. With less generous terms of credit and less 
credit directed towards SOEs per se, Taiwanese SOEs never had quite the opportunity to amass the resources to become too big to fail. Furthermore, the financial system did not give them such lavish treatment in terms of the interest rates that they could rely on being embedded within the current system alone to survive i.e., these firms were always more market-facing with fewer resources than China's big SOEs. Thus, their motivations to engage in IW to maintain the current system of financial repression were weaker.

Thus, we formulate the following propositions:

Proposition 1a: The greater the financial repression in a country, the greater the motivation of this country's SOE TMTs' for undertaking IW.

Proposition 1b: The greater the financial repression in a country, the more SOEs are encouraged to grow in size, thus accumulating valuable resources for IW and consequently expanding the scope for SOE TMTS' IW.

\subsubsection{Industrial policy}

Industrial policy refers to a heterogeneous and evolving set of policy goals and instruments targeting the structure of an economy to improve its growth potential (see e.g., Rodrik, 2004, 2007). Following Warwick (2013), industrial policy is "any type of intervention or government policy that attempts to improve the business environment or to alter the structure of economic activity towards sectors technologies or tasks that are expected to offer better prospects for economic growth or societal welfare than would occur in the absence of such intervention." (Warwick, 2013, p. 16). Historically, state ownership has been a major instrument of industrial policy - especially in the immediate post-World War II period, when state ownership, associated with economic planning often constituted the core of industrial policy strategies in advanced economies (Nude, 2010). Subsequent decades starting in the 1970s and 1980s saw a reduction 
in the role of SOEs (Toninelli and Toninelli, 2000). However, the recent rise of economic regulation, originally thought of as an alternative to industrial policy, has not put an end to the state's role in the economy nor to state ownership (Vogel, 1996; Thatcher, 2014). Quite the opposite: partial privatization and sale of shares has enabled SOEs to internationalize, expand into new markets and establish alliances with private firms, becoming truly "national champions" (Thatcher, 2014).

Industrial policy to the extent that it utilizes SOEs as the targeted firms enhances the resource endowments and motivation for institutional work. For example, Datang Telecommunications in China took advantage of SOE-centric policies in the telecommunications and semiconductor industries to accumulate resources and motivation for IW. Embracing China's 3G TD-SCDMA technology strategy allowed Datang to survive in a period where its market share had fallen precipitously low. These SOE-friendly industrial policies also incentivized Datang to push for further industrial policies. The firm then used these resources to play an active role in investing in the semiconductor industry and concomitantly to push the state to create even more ambitious, SOE-friendly industrial policies (Fuller, 2016).

This leads us to formulate the following propositions:

Proposition 2a: The more active an industrial policy incorporating SOEs, the more SOEs have a stake in the industrial policy, heightening SOE TMTs' motivation to engage in IW.

Proposition 2b: The more active an industrial policy incorporating SOEs, the higher the strategic value and/or increase in size of SOEs and, therefore, the more resources may a SOE draw on for IW - and, consequently, the greater the scope for SOE TMTs' IW.

Proposition 2c: The more active an industrial policy incorporating SOEs, the more numerous and the wider the channels of state-SOE relations - and, consequently, the greater the scope for SOE TMTs' IW. 


\subsubsection{State-SOE governance system}

\subsubsection{Structuration of authority within state shareholdings}

State-SOE relations are structured by a certain state-SOE governance system that determines the lines of command and authority. These can be more or less centralized within the state apparatus and more or less fragmented across state agencies (see e.g., Marquis, Zhang \& Zhou, 2011 on China). These structural components of the state-SOE governance system determine what we label the "structural" autonomy of SOEs vis-a-vis state bureaucrats and agencies. However, beyond its structural aspect, SOE autonomy also encompasses less structural links such as TMT's social links to parts of the state bureaucracy or policy-makers. These aspects the "social" autonomy of SOEs vis-a-vis state bureaucrats and agencies - are addressed in subsection 3.2.2.3 below. Also, we distinguish lines of authority from ownership ties (discussed in section 3.2.2.2). SOEs are embedded in structures of control and supervision that may or may not be underpinned by ownership ties. Thus, central banks or ministries of finance can have oversight rights over SOEs regardless of whether or not they have ownership stake in the SOEs they oversee. We therefore discuss ownership ties separately in the next section.

International financial institutions usually distinguish three types of SOE governance structures. First, there is the traditionally wide-spread decentralized model where various 'line ministries' directly control and manage their ownership rights over their own portfolio of SOEs. Second, there is a so-called "dual model" where line ministries exercise their ownership rights over SOEs, with the Ministry of Finance exercising some overarching oversight over financial performance (OECD, 2005b, 2015a; World Bank, 2006, 2014). Third, there is a centralized model where the management and control over state-owned assets is unified in a single entity that manages these assets based on financial and commercial rather than political criteria. Such 
financial management vehicles for SOE governance are typically asset management entities. Recent reform guidelines by the OECD and the World Bank are encouraging a move away from the decentralized model towards the fully centralized one, with the "dual model" constituting an acceptable "second best" solution. For our purpose, the key difference is whether or not the designated state unit or units govern the SOE through indirect, financial means or through direct intervention into the management of the SOE. Indirect financial means are financial performance targets. The international organizations' preference for the centralized model stems from the belief that such a structure will isolate SOEs from undue direct political interference from politicians, making SOEs more focused on financial goals and thus more efficient. Indeed, such "agencification" - whereby ownership and control over SOEs is transferred from bureaus within the state bureaucracy to autonomous agencies - will lead to stronger incentives for SOE TMTs to pursue and deliver on commercial goals (Vining et al., 2015).

The indirect, financial model of governance has two contradictory effects on the likelihood of SOEs to perform IW: this structure implies a heightened financial and commercial accountability towards the asset managing entity. SOEs will be pushed to more narrowly focus on commercial and financial goals. At the same time, indirect asset management entities have a more limited mandate and goals and fewer resources at their disposal. From the SOE perspective, replacing state agencies' direct management control with state agencies utilizing indirect, financial control therefore implies a decrease in the resources they can draw on to perform IW. According to our model, this will negatively affect SOE's scope to perform IW.

On the other hand, however, the indirect, financial governance structure means SOEs are politically more autonomous from the state as it becomes harder for politicians to control SOEs directly (World Bank, 2014: 79). Indeed, "agencificiation" has been shown to lead to increased managerial discretion towards the state (Vining, Laurin, \& Weimer, 2015). We would therefore 
expect that SOEs embedded in a governance structure that isolates them from direct managerial control will have more leeway to pursue IW especially when their goals diverge from the government's goals.

In France, for instance, all state shareholdings are managed by a specialized entity, the Agence des Participations de l'État (APE), created in $2004^{[11]}$, which is autonomous from the Treasury. Of course, although an autonomous entity, APE has very close ties to the Treasury, both in terms of its governance and of its staffing: as pointed out by the Cour des Comptes (France's supreme public accounting body) in a 2017 report, the 4 most senior positions at APE are held by members of the Treasury. Yet, the objectives of APE are very different from the very traditional hierarchical relationships characterizing the Treasury-SOE relationships in the postwar era. The goal is to use equity ties to sustain "national champions" or companies representing the "national interest" - which is, as per APE's official mission statement to "embody the shareholder State" by investing into companies "deemed strategic by the state", "to stabilize their equity or accompany them in their development or transformation." ${ }^{[12]}$ For SOEs this change in governance structures does mean to become more isolated from the more political goals of the Treasury, which increases their structural autonomy.

Emerging and developing economies, too, have started reforming their SOE-governance structures, with potential implications for SOE scope for IW. Thus, Paraguay implemented a reform in 2008 - under the maverick President Fernando Lugo - that centralized the SOE control and removed control from ministries to transfer it to an inter-ministerial SOE Council supported by a SOE Monitoring Unit (World Bank, 2014: 268-9). While political influence in this system is still potentially strong, because ministries remain represented on the Council, SOEs are more isolated from political interference by individual ministries and may benefit from more political leeway due to the multiplication of potentially divergent political interests represented on the SOE Council. Taken together, these developments in SOE governance are 
likely to favor both market and nonmarket strategic autonomy by SOEs, thus enlarging the scope for IW.

Thus, we make the following propositions:

Proposition 3a: SOEs governed by a state agency through indirect, financial mechanisms rather than governed by a state agency with direct managerial control, will have fewer resources and hence more limited scope to engage with IW.

Proposition 3b: SOEs governed by a state agency through indirect, financial mechanisms rather than governed by a state agency with direct managerial control, will have greater political autonomy and hence scope for IW.

Which effect will dominate (reduced resources or increased political autonomy), is contingent on the factors enunciated in Propositions 5a and 5b below. The state's ability to control SOEs is dependent upon the political integration of SOE elites with other state states and the nomenklatura system in each polity. It is also important to acknowledge that these propositions are not standalone ones, and our integrated approach to SOE IW requires combining the considerations from different propositions in order to assess SOE IW behavior.

\subsubsection{Degrees of state ownership}

Closely related to the factor mentioned above is the extent or degree of state shareholdings in SOEs. We know from the existing literature on state capitalism that there is significant variation in the degrees of state ownership across countries and across SOEs. This has led Musacchio and Lazzarini, in a series of works, to contrast "Leviathan as a minority investor" with "Leviathan as a majority investor" (Inoué, Lazzarini \& Musacchio, 2013; Musacchio \& Lazzarini, 2014; Musacchio, Lazzarini \& Aguilera, 2015; Lazzarini \& Musacchio, 2018). There is increasing empirical evidence that these two modalities of state ownership generate effects on SOEs' strategic behavior (Musacchio, Lazzarini \& Aguilera, 2015). In particular, Arreola 
and Bandeira-de-Mello (2018) and Kalasin et al. (2020) show how different degrees of state ownership affect SOEs' internationalization. According to Inoué and colleagues (2013), varying degrees of state ownership translate into different degrees of firm-level performance. Further, as demonstrated by Cui and Jiang (2012), different levels of state ownership are also associated with varied degrees and types of institutional pressures experienced by SOEs. It is thus reasonable to expect that the degree of state ownership is likely to affect SOEs TMTs' willingness and capacity to perform IW.

Importantly for our purpose here, the above-mentioned literature shows that there is no linear or constant relationship between state ownership and SOE behavior and/or performance. This reflects the contradictory effects of state control. Within the framework of Musacchio and Lazzarini (see, in particular, Musacchio \& Lazzarini, 2014), the causality between state ownership and SOE performance runs like this: varying degrees of state ownership determine degrees of state control, which affect the ability of SOE managers to pursue objectives of their own - their own interest, assumed to diverge from state actors' interest. In this view, greater performance is associated with lower degrees of control because the latter enable SOE TMT to evade political interference. Thus, decreasing state ownership will favor SOE's strategic autonomy, to the benefit of firm-level performance. On the other hand, with state ownership come resources: in particular, state ownership promotes capital expenditure in SOEs facing constraints on their ability to fund investment - for instance, because of a defective institutional environment (Inoué et al., 2013). Thus increasing state ownership is associated with increasing firm-level performance. The overall, net effect of state ownership is thus theoretically indeterminate, and can only be assessed empirically (Lazzarini \& Musacchio, 2018).

Similarly, Kalasin et al. (2020), find an "S-shaped" relationship between state ownership and internationalization of SOEs: low degrees of state ownership are associated with low internationalization; ${ }^{[13]}$ as state ownership increases, internationalization increases, until it 
decreases again with high degrees of state ownership. This S-shaped relationship is due to two opposite effects of state ownership, according to Kalasin and colleagues (2020): a "hindering hand" effect, whereby increasing state ownership compounds multilevel agency problems and a "helping hand", whereby increasing state ownership provides SOEs with increasing resources. This argument is very much in line with the agency framework proposed by Musacchio, Lazzarini and colleagues (Inoué et al., 2013; Lazzarini \& Musacchio, 2018).

While we hypothesize, similarly, that varying degrees of state ownership will lead to different degrees of likelihood of SOEs performing institutional work, our explanations differ from those offered by Musacchio and Lazzarini and Kalasin and colleagues on two grounds. First, institutional work is not exclusively driven by attempts to challenge the government's orientation or to change the institutional work in a way that better fits an SOE's TMT's goals or interests; as argued in the previous section, SOEs might have a stake in / SOEs TMT might be interested in maintaining the existing institutional framework, i.e. in performing institutional work that strengthens the government's policy goals. This understanding of IW, drawn from the IW literature (Micelotta \& Washington, 2013), is compounded by our own assumptions regarding the drivers, or motivations, of SOEs TMT. In particular, we reject the agency view of the relationship between SOE TMT (the agents) and state bureaucrats (the principals), which posits that agents will tend to pursue different interests (and certainly not political ones) from the principals. By contrast, we have argued in Section 3.1.3 above that we hold the goals driving SOE TMTs to be much more multi-faceted than in this narrow agency view. Thus, we do not assume an a priori divergence or alignment of interests between state bureaucrats and SOE TMTs.

For these reasons we do not hold the view that an increased degree of state ownership may reduce IW by impeding SOE managers to further their own interests and, accordingly (with the narrow agency view), seek to change their institutional environment. Rather, we hypothesize 
here that if varying degrees of state ownership have an effect on the likelihood of IW on the part of SOEs, such effect is not linear, due to the concurrent causal mechanisms that relate degrees of state ownership with SOE's IW. In particular, we argue that increasing state ownership does not act only as a deterrent for (institutional) action on the part of SOE managers, as held by Cui and Jiang (2012). In this case, as at other levels of the institutional environment faced by SOEs, institutions may act as enablers of agency. In particular, increasing state ownership may generate increasing political resources that will feed into SOEs' IW. For example, SMIC, China's largest integrated circuit manufacturer, had minority stakes from the central government and Shanghai government, and as a consequence, despite its large size, was not prioritized by the central government or Shanghai government and had little influence over China's IC industry policies (Fuller, 2016). Importantly, the political resources created by state ownership are often associated with non-ownership related factors, such as the embeddedness of SOE TMTs within networks of state bureaucrats. But these two sets of factors are analytically distinct, and the effects of varying embeddedness will be discussed in the next subsection.

Such political resources contribute to opening up scope for institutional work on the part of SOEs. Scope, however, does not depend on political resources only; it also directly reflects the opportunities to act built into SOEs' institutional environment. Therefore, it is reasonable to expect that as state ownership increases, causing political resources to rise, scope for IW will increase as well. However, scope is also increasingly limited by the degree of state control that, as state ownership increases, also increases. A good illustration of this is France's Engie, partially owned by the French State (with a $24 \%$ equity stake), which is simultaneously much more proactive with respect to regulatory reform than GDF, its fully state-owned predecessor, and less imbued with political resources necessary for successful IW, a fact illustrated by the recent turnover at the helm of the company. ${ }^{[14]}$ 
Here the logic of our argument is not fundamentally dissimilar to the one put forward by Lazzarini and Musacchio (2018) whereby the good performance of SOEs across the world (across their panel) may be attributed to the extra resources provided by state ownership. Of course, in Lazzarini and Musacchio's framework, these resources (which they call "protection" and "rents" rather than political resources) only mitigate the negative impact of state ownership on SOE performance via agency conflicts. We, on the other hand, do not think about TMT's interests and goals as a priori misaligned with state bureaucrats' goals.

As explained in Section 3.1.3, we construe the motivation of SOEs' TMT as (a) reflecting multiple potential goals and (b) being affected by TMT's perceived scope for action. In other words, we have argued that the perception of opportunities to maintain or transform SOEs' institutional environment prompts actors to enact their goals in that regard.

In accordance with the above discussion, we hold that degrees of state ownership have indeterminate effects on the "interest/goals" drivers of SOE TMT motivation (to do IW). In other words, varying state ownership does not imply greater alignment / divergence of interest between state bureaucrats and SOEs TMT. If motivation to perform IW is affected at all by degrees of state ownership it is through its relationship with scope - i.e. because of the perceived opportunities for IW (Dorado, 2005; Battilana et al., 2009); like scope, therefore, the motivation of SOEs TMT to perform IW will rise with increasing degrees of state ownership, until the high degree of state ownership starts reducing scope and, consequently, disincentives SOEs top management to seek to act in order to change or maintain their institutional framework. This argument is similar to the one made by Boies on large American firms' political activities, whereby a firm's interest in engaging in CPA is compounded by the extent and depth of that firm's relationship with the state apparatus (Boies, 1989). 
We do argue that greater state ownership ceteris paribus provides greater political resources via two mechanisms. Increasing state ownership increases the formal and informal interactions between the SOE TMT and the state and thus enhances TMT's political resources by expanding informal and formal ties to other state elites. Increasing state ownership also increases the economic and strategic value of the SOE in the eyes of the state. The SOE TMT can wield this enhanced valuation as a political resource.

Hence, we put forward the following propositions:

Proposition 4a: The higher the degree of state ownership, the more political resources SOE TMT may draw on, and the higher the scope to engage in IW on the part of SOE TMTs.

Proposition 4b: There is an inverted u-shape relationship between the degrees of state ownership and SOEs' scope for IW: as state ownership increases, so will the state control, leading to reduced scope for SOE TMTs' IW, counterbalancing the increased scope from greater political resources.

Proposition 4c: There is an inverted u-shape relationship between the degrees of state ownership and SOEs' motivation to engage in IW: as state ownership increases, there will be greater political resources and, consequently, greater scope for IW enhancing SOEs TMTs' motivation to act (regardless of their goal divergence / alignment with those of state bureaucrats); with a high degree of state ownership, however, reduced scope for IW diminishes the motivation to perform it.

For Propositions 4B and 4C, we acknowledge that the level of state autonomy in terms of how impervious the state is from interference will change the shape of the curvilinear effect. The more state autonomy the flatter the curve of increased scope from greater political resources (Proposition 4B) and the flatter the curve of increased motivation from political resource-based scope (Proposition 4C). Political science scholars from a wide variety of traditions have 
arrived at something approaching a consensus on the basic requirements for state autonomy: 1) broad political coalition supporting the state (Acemoglu and Robinson 2012; Evans 1995; Kohli 2004; Haggard 2018) and 2) professionalization of the state bureaucracy (Fukuyama 2013; Johnson 1982; Haggard 2018; Rauch and Evans 2000; Wade 1990).

\subsubsection{Top management embedding in political system: Political and nomenklatura ties}

State-SOEs relations do not start and end with equity ties. Other, non-equity relationship tie SOEs to the state apparatus, and also affect the nature and scope of SOEs' IW. In particular, we argue that SOEs' political ties are a crucial determinant of the latter. This argument is parallel to that made by Schneider when analyzing the role of personal networks in determining the political strategies of business in South America (Schneider, 1992). As argued by Schneider, they were especially significant in the case of Mexico, Chile and Colombia throughout the 20th century, where business associations formed the locus of tight informal ties between businesses and politicians, enhancing the collective action of businesses with regard to government policy and regulation.

The economic literature - particularly agency theory - has often treated political ties as constraints negatively affecting SOEs' operations and bottom lines. In this perspective, state control carries with it a political logic, alien to the business objectives of the firm, thereby hampering these objectives and damaging its performance (Shleifer and Vishny, 1998; Shirley

and Walsh, 2000). The management literature qualifies this picture, underscoring the benefits that companies can draw from ties with the state. Indeed, such ties can increase performance by permitting access to resources, information and preferential treatment (Xin \& Pearce, 1996; Johnson \& Mitton, 2003; Lester et al., 2008). Okhmatovskiy (2010) argues that ties with the government may be important for firms to influence policies, although they may not help in accessing resources. However, Sun and colleagues (2010) find that the value of political ties 
can change dramatically as a country's institutional system moves towards a more market-based system. In short, political embeddedness does have important, if complex, implications for firms.

For SOEs, ties to the government are a key channel of influence. Recent literature shows that the ties that bind SOEs to state agencies and bureaucrats are multiple and heterogeneous (see Cuervo-Cazurra et al., 2014), including equity (minority and majority shareholdings), debt (subsidized credit), board seats, regulation, and other, softer forms of control, such as staffing and contracts. There is also a great variation in the legal status and degree of state embeddedness of SOE staff: from SOEs employees as civil servants to a complete separation between careers of state employees and SOE employees (see e.g., Liang, Ren \& Sun, 2015; Grindle, 2010). Political ties can take several forms, from interchangeable career paths (revolving doors) to common educational backgrounds. Various studies have pointed to the links between political and managerial careers as a key component of state capitalism in China (see, in particular, Boisot and Child, 1988; Groves et al., 1995; Fan et al., 2007; Lin et al., 2013). In France, a high proportion of senior staff and top managers at the largest French firms have historically been trained in the prestigious "Grandes écoles" system that works as a breeding ground for future civil servants. In 2010 still, according to one study, 41\% of top managers in SOEs belonged to state corps (Dudouet \& Joly, 2010). This peculiar form of socialization ensures common views and informal communication channels between state authorities and SOEs. But this shared background is not limited to public enterprises: more generally, a high proportion at the largest French listed firms still, in the early 2000s, shared the same education and training with top civil servants; a phenomenon that endures despite privatization and globalization, leading Dudouet and Joly (2010: 43) to qualify this as the "survival of a relationship with the State through the grands corps". 
In a number of state-planned and formerly state-planned economies, the state often attempts to exert strict control over SOEs' TMT via bureaucratic procedures concerning personnel or "nomenklatura", which derives from the Russian term for the list of important posts in government and industry to be filled by Communist Party members in the Soviet Union. For example, in China nomenklatura refers to lists of positions directly appointed by the CCP's Central Organization Department (Leutert, 2018). When this nomenklatura system functions in terms of its Leninist intent, the party-state exerts strong control over the appointment and monitoring of the top management team in SOEs. In such situations, one would expect the SOEs would have little space in which to pursue IW. However, if the nomenklatura system is fractured or the SOEs can somehow buck the control of the nomenklatura system through playing the party-state organ in charge of nomenklatura against other party-state organizations in control and monitoring of the SOE, then the SOE can have more space to pursue IW. For example, among China's central government SOEs, some are formally under SASAC's control $^{[14]}$, but the Organization Department and the SOE top managers' own accumulated rank and power can be used to thwart control by SASAC or any other authority (McGregor, 2012; Walter \& Howie, 2011).

It is important to draw a clear distinction between the functioning of the nomenklatura system and the level of integration of SOE management into the wider political elite. A functioning nomenklatura system means that the party-state maintains effective control over the SOE management it appoints. However, integration of the SOE managers into the political elite has often led to the breakdown of nomenklatura control as SOE managers either outrank their nominal supervisory agencies or their connections to top leaders thwart such control.

There is an indeterminate relationship between political embeddedness of the TMT and motivation. On the one hand, the more embedded the TMT is in the political system the more it has the political resources and enhanced scope for institutional work. Enhanced scope feeds 
back into enhanced motivation. On the other hand, the greater the political embeddedness of the TMT, the less likely the TMT will be motivated to engage in institutional work because the TMT will be more likely to embrace whatever beliefs about institutional creation, maintenance or disruption the ruling political elite has. With ideological agreement with the political leadership, the TMTs will be passive followers rather than active champions of institutional work.

Thus, we argue:

Proposition 5a: The higher the integration of the SOE TMT into the political system, the higher the political resources the SOE may draw upon ceteris paribus the more scope for IW by the SOE TMT.

Proposition 5b: The stronger the control of the nomenklatura system, the lower scope and thus motivation the SOE TMT has to engage in IW.

Proposition 5c: The higher the political skills of individual members of the SOE TMT the more likely the SOE will garner political resources and be able to evade nomenklatura control and thereby enhance the SOE TMT's scope for IW.

\subsubsection{Alliances with non-state stakeholders}

Although close ties to the state and political decision-makers provide SOEs with IW-enabling political resources, a key question remains of how SOE TMTs create a degree of autonomy from the state bureaucracy in order to increase their scope and enhance their motivation to perform IW. In line with the previously discussed 'power escape' argument (Cuervo-Cazurra et al., 2014; Huang, Xie, Li and Reddy, 2017; Cui \& Xu, 2019), which postulates that SOEs can reduce their political liabilities by reducing their dependence on the state, not least through 
external connections, strengthened by HI's emphasis on the "coalitional foundations" of processes of institutional change (Thelen, 2004, 2012), we argue that this might be achieved by nurturing alliances with a range of relevant non-state stakeholders.

Research in the post-socialist context provides insights into the mechanisms and outcomes of such alliance forging (Clark \& Soulsby, 1995; McDermott, 2007). For instance, Markus's work shows that firms actively use coalition-building to protect themselves from state predation or indeed predation by private actors. Such stakeholder alliances initiated by firms can lead to the emergence of what Lawrence, Hardy and Phillips (2002) called 'proto-institutions.' This “local informal consensus regarding property rights' protection" often "preexisted (and was later acknowledged by) formal national institutions" (Markus, 2012: 272). As such, firm strategies can become the kernel of bottom-up institution building and change.

Markus (2008) has shown in the case of private firms in Russia under the Putin government of the early 2000s that voluntarily implementing firm-level corporate governance reforms that go beyond the legally required minimum allows firms to attract foreign investors, which then become the firm's 'political insurance' against state predation. More generally, in contexts of either predatory states or weak states that cannot enforce property rights against private actors' predatory behaviours, Markus (2012: 274) demonstrates that "by forging alliances with stakeholders around their firms, owners force the state and rival businesses to respect their rights." The argument can be extended at least to listed and partial SOEs: SOE TMTs may be able to implement best practice to attract foreign investors who become allies that may defend the SOE's autonomy from the government. Stark's (1996) notion of 'recombinant property' based on the Hungarian case describes a similar ownership-based strategy by firms (newly privatised or partially state-owned) to create some stability and certainty in a context where formal institutions are weak. By integrating foreign ownership into such 'recombinant property' networks, firms in Hungary have found an effective organisational response to the challenges 
of an uncertain institutional environment and an increasingly internationalised economy (Stark \& Vedres, 2012). Creating network ties through ownership strategies may well be a way in which SOEs bolster their autonomy from a one-sided overdependence on the state.

In addition to ownership strategies, SOEs can build stakeholder alliances in a number of ways, including diversifying their political ties through strategic board appointments (Wang, Jin \& Yang, 2016; Musacchio \& Lazzarini, 2018), forging links with local communities (McDermott, 1997; Markus, 2015), and commercial contracts. Choudhury and Khanna (2014), for example, showed that Indian state-owned laboratories increased their "global footprint" by licensing patents to major multinational firms, thus generating a cash flow independent of the Indian state.

Corporate social responsibility strategies constitute another important means by which firms pursue alliance building (Markus, 2008; Johns \& Wellhausen, 2016). Frye (2006) has shown how newly privatised firms invest in public goods in order to increase their legitimacy in the broader population arguably reducing the risk of renationalisation by the state. Such legitimacy strategies can be expected to be open to SOEs, too, if we accept that SOEs have some autonomy from the State to begin with and thus can make such strategic investments in legitimacyenhancing projects (Marquis, Yin \& Yang, 2017).

Based on these arguments, we propose:

Proposition 6: The more SOE TMTs form coalitions with stakeholders outside the state sphere, the higher their scope and motivation to perform IW.

\subsubsection{Industry characteristics}


Industry characteristics shape the resources SOEs have for IW. Several resources stand out in particular size and strategic value. The latter are likely to be particularly influenced by vertical integration and technical change within a given industry and time period.

Drawing on the industrial organization-inspired works of the classic external approach to strategy (cf. Porter, 2008), vertically integrated firms can lower competition in their industry (i.e., increase their market power) by threatening suppliers and even buyers with backward or forward integration, and this threat is more credible when a firm already is quite vertically integrated. As a parallel to this firm-level strategy view, firms have greater clout in their respective economy the more market power they exercise. Furthermore, this clout is also enhanced in vertically integrated industries because the firms tend to be bigger in such industries. Industrial policy interacts with this tendency for vertical integration in that under conditions conducive to vertical integration the state will favor a select few national champions in sectors that favor vertical integration (Gerschenkron, 1962; Nolan, 2001) and thus provide the targets of such industrial policies with even more resources.

Conversely, the global value chains and other industry studies literature recognize that there are often sectoral pressures for segmentation/de-verticalization/disaggregation of the value chain (Arndt \& Kierzkowski, 2001; Berger, 2005; Fuller et al. 2003; Gereffi et al., 2005; Langlois, 2003; Thun, 2007). With the fragmentation/disaggregation of value chains, small firms engage a multitude of external suppliers while concentrating/specializing on a narrow band/segment of activity (Fuller, 2013; Thun, 2007). Thus, vertically disintegrated value chains tend give rise to vertically specialized firms that have less strategic value and smaller size so the SOEs in such industries will be hard pressed to leverage their limited value and size as vertical specialists to enact IW. 
While much of the work on vertical specialization assumes that it depends on the sector or subsector (Berger, 2005; Fuller et al. 2003; Gereffi et al., 2005; Thun, 2007), there are arguments that different periods of time favor either more vertical integration or vertical specialization. Scholars of industrial change (Gereffi et al. 2005) have argued that a combination of high complexity of information, transaction costs and asset specificity will encourage vertical integration. Critically, these factors combine in a tipping point fashion to move from industries favoring de-verticalization to ones favoring vertical integration. Thus, the proposition does not include these three factors as metrics as it is only when the three reach some critical threshold that vertical integration becomes the dominant competitive mode of organization. Many have talked about distinct periods favoring vertical integration and other periods favoring greater vertical specialization (Langlois, 2003). While there is some debate (cf. Newman \& Zysman, 2006) as to how strong these wider, cross-sectoral trends are, to the extent that they exist, periods of vertical integration should be ones where SOEs enjoy relatively greater capacities to pursue greater IW compared to periods of vertical specialization. Historically, these periods of vertical integration and industrial concentration enhanced the strategic value and logic of using SOEs to pursue industrial success because many states felt more comfortable handing the keys to the commanding heights of the economy to a select small group of firms directly under government ownership (Hsueh et al. 2001; Amatori, 1997). Conversely, in periods of vertical specialization, these state-owned industrial behemoths begin to look outdated, costly and unnecessary so SOEs lose strategic value in addition to scale due to shedding what have become scale diseconomies in the new period of vertical disintegration. For example, French, Italian and Taiwanese models of vertical integration predicated in large part on SOEs in the 1950s and 1960s began to face pressures during the 1970s (Zysman, 1977; Piore \& Sabel, 1984; Hsueh et al., 2001).

We therefore propose: 
Proposition 7a: To the extent that a certain period/sector favors vertically integrated, scale economy-based competition, SOES will tend to have greater strategic value and larger size, thus enhancing their resources and therefore increasing SOE TMTs' scope for enacting $I W$.

The faster the pace of technical change (incorporating both fast product life cycles and fast clockspeeds ${ }^{[15]}$ ) in a given industry is, the more likely it is for newcomers to disrupt incumbent firms' competitive advantages (Christensen 1997; Utterback \& Suarez 1993; Fine 1998, 2000). Therefore, incumbent SOEs in industries with a fast pace of technical change will be more likely to become less strategically valuable (in the eyes of state bureaucrats or politicians) and/or have diminished resources. SOEs in those industries will, as a result, have fewer resources to pursue IW.

It must be conceded that fast clockspeeds sometimes will work via mechanisms covered in other propositions. For example, fast clockspeeds often accelerate vertical specialization (Steil et al., 2002; Fine 1998). However, this is dependent on the extent of standardization with nonstandardized activities difficult to de-verticalize (Christensen, 1997). In a similar fashion, in those sectors with a fast pace of technical change, state industrial targeting is probably less effective as state policy has difficulty keeping pace with changing requirements within the industry (Schmitz, 2007). Thus, we could imagine that industrial policy in these sectors would be less effective in building up the resources SOEs draw upon to engage in IW.

We therefore formulate the following proposition:

Proposition 7b: To the extent that fast pace of technical change is prevalent in a given industry, leading the state to deprioritize established SOEs thus leading to fewer resources and therefore lower scope for these SOE TMTs to enact IW.

It should be acknowledged that there could be institutional feedback mechanisms from contexts favoring vertical integration into an industrial policy incorporating SOEs (i.e., Propositions 2a, 
$\mathrm{b}, \mathrm{c})$. However, this is not the only mechanism through which industrial characteristics affect SOE TMTs' IW.

\section{DISCUSSION AND CONCLUSION}

The return of SOEs as major players in the world economy has sparked a new interest in their diversity and the institutional determinants of their strategy and performance (Musacchio et al., 2015). With few recent exceptions, most theories suggest that SOEs are merely agents of the state that are closely controlled through personal and ownership ties amongst others. As a result, the question of SOE agency has received only very limited attention. The study of the internationalization of SOEs, for instance, has at times hinted at a certain divergence of SOE and state preferences (Rodrigues \& Dieleman, 2018). Thus, internationalization may provide SOE top managers with a means of emancipating themselves somewhat from too close governmental control. These findings suggest that SOEs do have considerable leeway even though they are integrated to some extent into the state structure of the country. The purpose of our paper was to suggest that these findings from the case of SOE internationalization may apply much more broadly to SOEs' ability to shape their institutional environment through institutional work, as hinted in the more micro-level studies examining the institutional agency of SOE managers (Guo et al., 2017; Raynard et al., forthcoming). Focusing on situations where SOE TMTs may attempt to either promote or oppose institutional change in their home country, we attempted to develop a systematic model that explains what factors determine the extent of leeway they might have to exercise institutional work. Our propositions and examples are summarized in Table 2.

\section{[INSERT TABLE 2 ABOUT HERE]}

Our multilevel model consists of eight factors at three different institutional levels that shape SOEs motivation, resources, and scope to perform institutional work. The propositions that 
we have formulated regarding these eight determinants of SOE work, should be seen as cumulative and complementary. Our argument is that an SOE embedded in a context - macro (institutional), meso (governance system), and industry - characterized by determinants that favor SOE IW, will be more likely to engage in such activity than an SOE embedded in an institutional framework where elements are present that constitute barriers to SOE IW by either reducing their motivation, resources, or scope to perform IW. Thus, an SOE embedded in an institutional system with financial repression, active industrial policy towards SOEs, fragmented lines of authority, autonomous state shareholdings agency, sizeable minority shareholdings by the state, medium degree of integration with the nomenklatura, vertically integrated production, and slow product life cycles will be very likely to engage in IW to either support or resist institutional change. An SOE in an institutional system where these factors are absent or point in the opposite direction will be likely to be pure agents of the state.

Our theoretical contribution is fourfold. First, we contribute to the SOE literature by extending existing studies of the institutional embedding of SOEs (Cui \& Jiang, 2012; Fuller, 2016; Fuller, Shih \& Tao, 2015; Huang, 2003; Inoué, Lazzarini \& Musacchio, 2013; Musacchio \& Lazzarini, 2014; Musacchio et al., 2015; Lazzarini \& Musacchio, 2018). Our paper builds on these studies but adds to them by providing a framework that can explain when and why SOEs may break free from the control of the state and pursue their own (institutional) strategic interests, and also conceptualizing SOE institutional agency as not strictly a byproduct of potential agency conflicts between the SOE managers and the state. Given the increasing importance of SOEs in the world economy - both domestically and internationally - the alignment or divergence of interests, preferences, and motivations between SOEs and the governments who control them is a tremendously important issue not just for management scholarship, but also for policy makers interested in questions of national security. 
Second, we build on the complementarities between IW and HI to contribute to HI theories of institutional change, by highlighting the "upstream" factors that may drive individual SOEs to pursue institutional change (or maintenance), regardless of their position as "change agent" within processes of institutional change (Mahoney and Thelen, 2010). This could improve HI accounts of institutional persistence or limited institutional change by identifying additional factors through which the "coalitional foundations" (Thelen, 2004) of institutions may change (or not). Critically, our theoretical focus on micro-mechanisms of IW could help to flesh out the motivations and scope for active institutional maintenance that only some HI scholarship, such as Thelen (2004), have recognized.

Third, we leverage the insights from HI literature to contribute to theorizing on IW, particularly linking the "positions, endowments and capacities of societal actors" with their capacity to perform institutional work (Hotho \& Saka-Helmhout, 2017: 10). Responding to the calls by Hwang and Colyvas (2011) to engage more critically with the context of IW and extending the work of Battilana and colleagues (2009), we problematize SOE TMTs as a unique type of institutional actors (cf. Yan et al., 2018) and identify a series of institutional determinants across multiple levels of analysis that explain in what settings their IW is more or less likely to occur. Further, while we use an IW perspective to complete a broader HI understanding of embedded agency at the heart of processes of institutional change and persistence, we also draw on HI's political economic conceptualization of institutional dynamics to compensate for the limitations of IW. We particularly strengthen and expand the understanding of the state and state-affiliated actors in IW, which to date has been relatively narrow (Clegg, 2010), and often confined to policing existing rules or initiating policy change endorsed or resisted by focal actors.

Lastly, by drawing on a range of examples we also hope to have contributed to the research on transition economies by highlighting similarities across salient elements of the institutional environment and SOE experiences in transition and market economies. A growing number of 
studies has started to explore agency by SOE managers, particularly in the context of China (Guo et al., 2017; Raynard et al., forthcoming), our frameworks outlines enabling and constraining conditions for IW that are likely to be shared across countries, thus enabling and encouraging further comparative work.

Our study has two main limitations. First, we purposely focused on the determinants of IW by SOEs. Our framework therefore does not allow us to understand under what circumstances such activity - when it does take place - is likely to be successful or to fail. As we have argued earlier, this question is more likely to be successfully tackled through empirical research.

Second, our study drew on empirical illustrations from a limited number of countries. As such, we expected the choice of these countries to allow us to control for certain factors, but still provide some evidence for the breadth of the applicability of our framework. Nevertheless, it offers a research agenda with propositions that can and should be tested against evidence from a much larger number of countries and geographical regions.

Finally, a particularly promising avenue for extending our theorizing would involve disentangling the different types of IW (creation, disruption or maintenance) by SOE TMTs; and, in parallel, tie these different types to the different modes of institutional change identified by historical institutionalism. Although this discussion is beyond the scope of our paper, we expect that this discussion would further nuance the relationships outlined in our propositions.

\section{NOTES}

1. As such, we do not seek to explain the success or effectiveness of SOE IW in specific cases, but rather what makes them likely to engage in IW. Some of the factors in our framework that increase the likelihood of SOE engagement in IW will also increase - ceteris paribus - the chance of success of SOE IW - most importantly resources. Yet, in order to explain success or 
effectiveness of SOE IW, additional institutional factors would need to be taken into account, such as the shape of the political system (e.g., number of veto points), party strength etc. This is beyond the scope of this paper.

2. This differentiates the IW perspective from CPA, which harbors a narrower focus on improving the individual corporate position.

3. The literature on non-market strategies (such as CPA), which we have discarded earlier as the main basis for our theoretical framework, may be relevant here in so far as such strategies are instrumental in altering or maintaining SOEs' institutional environment.

4. The management literature generally distinguishes - although not always consistently 'resources' from 'capabilities,' with the latter referring to the firm's routines and skills that allow it to effectively use, leverage, or mobilize resources (cf. Schnyder and Sallai, 2020). Some authors explicitly talk about 'institutional capabilities' to designate organization-level routines that allow firms to mobilize resourced in order to adapt to new environments (Carney et al., 2017). Here, we use the term 'resources,' which refer to tangible and intangible and often less firm-specific assets than the inherently firm-specific, non-tangible notion of 'capabilities.' We do consider, however, that our arguments may apply to capabilities too.

5. Bonardi (2011) mentions other types of political resources beyond political ties, such as the ability of firms to threaten lay-offs - political resources based on economic assets. However, in the context of our framework, such broadly defined political resources might fall under the "size" or "strategic value" category.

6. A sizeable literature exists that investigates the role of firm-level variables, especially size, in determining the extent of lobbying activities. There seems to be empirical support positively linking size to lobbying capacity. See Drope and Hansen (2006), for a review and study on the U.S. case. 
7. We thus adopt a definition in line with the classic formulations of financial repression (McKinnon 1973; Shaw 1973). This is a narrower definition than the one used by some scholars, who include all sorts of regulation and interference in financial intermediation (Roubini \& Salai-Martin, 1995).

8. In banking, financial repression may also consist of "high, lowly compensated reserve requirements" (Clays et al., 2008).

9. Peng et al. (2016: 309-310) actually comes to close to recognizing the dilemma whereby SOEs strategically strive to enhance mutual dependence between themselves and the state and how that could block change. However, Peng and his co-authors concentrate on firm-level predictions and thus shy away from considering how the SOEs in pursuing this mutual dependence could substantially "freeze" the transition and maintain institutional arrangements that the authors themselves recognize will lead to sub-optimal outcomes for firm-level performance (assuming market competition) and efficiency.

10. See Lardy (2018), available at https://www.caixinglobal.com/2018-07-30/opinion-chinaseconomic-growth-falls-short-of-potential-101309877.html

11. By Decree n²004-963 of September 9, 2004.

12. APE mission statement, spelled out on the agency's official website: https://www.economie.gouv.fr/agence-participations-etat/notre-mission-statement (Accessed July 2018)

13. Similarly, in Cui and Jiang's (2012) study of Chinese SOEs, firms with lower share of equity held by the state were found to be less restricted by home-country institutions in choosing their international expansion strategies. 
14. The industrial clockspeed is the pace of technical change controlling for product complexity (Fine, 1998, 2000). It is important to note that clockspeed is $\underline{\text { not }}$ a measure of the technological intensity of the industry as some industries with slow clockspeeds, such as commercial aircraft with its product technology generations of ten to twenty years, are technologically intensive (Fine, 1998).

15. The ambiguous role played by the French State - as the dominant minority shareholder of Engie - is an additional illustration of the contradictory effects of minority state ownership on resources and scope. See https://www.latribune.fr/entreprises-finance/industrie/energieenvironnement/ce-ne-sont-pas-quelques-opposants-a-macron-qui-decident-du-sort-d-engiedans-les-coulisses-de-la-chute-precipitee-d-isabelle-kocher-838870.html 


\section{REFERENCES}

Acemoglu, D. and Robinson, J. 2012. Why Nations Fail: The Origins of Power, Prosperity and Poverty. Crown Business: New York.

Aguilera, R. V. \& Jackson, G. 2010. Comparative and international corporate governance. Academy of Management Annals, 4(1): 485-556.

Alami, I., \& Dixon, A. D. (2020). State capitalism(s) redux? Theories, tensions, controversies. Competition and Change, 24(1), 70-94.

Amatori, F. (1997). Italy: The Tormented Rise of Organizational Capabilities Between State and Markets. In A. Chandler, F. Amatori, and T. Hikino (eds.), Big Business and the Wealth of Nations, (pp. 246-276). New York: Cambridge University Press.

Arndt, S. W. \& Kierzkowski, H. (Eds.). 2001. Fragmentation: New production patterns in the world economy. OUP Oxford.

Arreola, F., \& Bandeira-de-Mello, R. (2018). The differential effects of minority state ownership types on the internationalization of emerging market multinationals from democratic states. Management International Review, 58(5), 845-869.

Battilana, J., \& D'Aunno, T. 2009. Institutional work and the paradox of embedded agency. In T. B. Lawrence, R. Suddaby, \& B. Leca (Eds.), Institutional work: Actors and agency in institutional studies of organization (pp. 31-58). Cambridge, UK: University of Cambridge Press.

Battilana, J., Leca, B., \& Boxenbaum, E. 2009. How actors change institutions: towards a theory of institutional entrepreneurship. Academy of Management Annals, 3(1): 65-107.

Berger, S. 2005. How we compete, New York: Currency/Doubleday.

Bernier, L. 2017. Public enterprises as policy instruments: the importance of public entrepreneurship. Journal of Economic Policy Reform, 17(3), 253-266. https://doi.org/10.1080/17487870.2014.909312

Bitektine, A., Haack, P., Bothello, J., \& Mair, J. (forthcoming). Inhabited actors : Internalizing institutions through communication and actorhood models. Journal of Management Studies. https://doi.org/10.1111/joms. 12560

Boddewyn, J. 1994. 'Political Resources and Markets in International Business: Beyond Porter's Generic Strategies', Research in Global Strategic Management, 4: 83-99.

Boies, J. L. 1989. Money, business, and the state: Material interests, Fortune 500 corporations, and the size of political action committees. American Sociological Review, 54(5): 821-833.

Boisot, M., \& Child, J. 1988. The iron law of fiefs: Bureaucratic failure and the problem of governance in the Chinese economic reforms. Administrative Science Quarterly, 507527. 
Bolino, M. C., \& Turnley, W. H. (2003). Going the extra mile: Cultivating and managing employee citizenship behavior. Academy of Management Executive, 17(3), 60-71.

Bonardi, J. P. 2011. Corporate political resources and the resource-based view of the firm. Strategic Organization, 9(3): 247-255.

Bremmer, I. 2008. The Return of State Capitalism. Survival: Global Politics and Strategy, 50(3): 55-64.

Bruton, G. D., Peng, M. W., Ahlstrom, D., Stan, C., \& Xu, K. 2015. State-owned enterprises around the world as hybrid organizations. Academy of Management Perspectives, 29(1): 92-114.

Choudhury, P., \& Khanna, T. 2014. Toward resource independence-Why state-owned entities become multinationals: An empirical study of India's public R\&D laboratories. Journal of International Business Studies, 45(8): 943-960.

Christensen, C. M. 1997. The Innovator's Dilemma: When New Technologies Cause Great Firms to Fail, Boston: Harvard Business School Press.

Clark, E., \& Soulsby, A. 1995. Transforming former state enterprises in the Czech Republic. Organization Studies, 16(2): 215-242.

Clegg, S. 2010. The state, power, and agency: Missing in action in institutional theory?. Journal of Management Inquiry, 19(1): 4-13.

Clegg, L. J., Voss, H., \& Tardios, J. A. (2018). The autocratic advantage: Internationalization of state-owned multinationals. Journal of World Business, 53(5), 668-681.

Cuervo-Cazurra, A., Inkpen, A., Musacchio, A., \& Ramaswamy, K. 2014. Governments as owners: State-owned multinational companies. Journal of International Business Studies, 45(8): 919-942.

Cui, L. \& Jiang, F. 2012. State ownership effect on firms' FDI ownership decisions under institutional pressure: A study of Chinese outward-investing firms. Journal of International Business Studies, 43(3): 264-284.

Cui, L., \& Xu, Y. 2019. Outward FDI and profitability of emerging economy firms: Diversifying from home resource dependence in early-stage internationalization. Journal of World Business, 54(4), 372-386.

Dorado, S. 2005. Institutional entrepreneurship, partaking, and convening. Organization Studies, 26(3): 385-414.

Drope, J. M., \& Hansen, W. L. 2006. Does firm size matter? Analyzing business lobbying in the United States. Business and Politics, 8(2): 1-17.

Dudouet, F. X., \& Joly, H. 2010. Les dirigeants français du CAC 40: entre élitisme scolaire et passage par l'État. Sociologies Pratiques, (2): 35-47.

Emirbayer, M., \& Mische, A. 1998. What is agency? American Journal of Sociology, 103: 962-1023.

Fan, J. P., Wong, T. J., \& Zhang, T. 2007. Politically connected CEOs, corporate governance, 
and Post-IPO performance of China's newly partially privatized firms. Journal of Financial Economics, 84(2): 330-357.

Fields, K. 1995. Enterprise and the State in Korea and Taiwan, Ithaca, NY: Cornell University Press.

Finchelstein, D. 2017. The role of the State in the internationalization of Latin American firms. Journal of World Business, 52(4): 578-590.

Fine, C. H. 1998. Clockspeed: winning industry control in the age of temporary advantage. Massachusetts: Perseus Books Reading.

Fine, C. H. 2000. Clockspeed-based strategies for supply chain design. Production and Operations Management, 9(3), 213-221.

Florio, M., Ferraris, M., Superiore, I., Boella, M., \& Vandone, D. (2018). Motives of mergers and acquisitions by state-owned enterprises A taxonomy and international evidence. International Journal of Public Sector Management, 31(2), 142-166.

Frye, T. 2006. Original Sin, Good Works, and Property Rights in Russia. World Politics, 58(4): 479-504.

Fukuyama, F. 2013. What is Governance? Governance, 26(3): 347-368.

Fuller, D. B. 2013. Building Ladders out of Chains: China's Hybrid-led Technological Development in Disaggregated Value Chains. The Journal of Development Studies, 49(4): 547-563.

Fuller, D. B. 2016. Paper tigers, hidden dragons: Firms and the political economy of China's technological development. Oxford: Oxford University Press.

Fuller, D. B., Akinwande, A., \& Sodini, C. 2003. Leading, following or cooked goose? Innovation successes and failures in Taiwan's electronics industry. Industry and Innovation, 10(2): 179-196.

Fuller, D. B., Shih, V., \& Tao, R. 2015. Market Governance and Firm Performance under China's State Capitalism. Management and Organization Review, 11(4): 711-713.

Garud, R., Hardy, C., \& Maguire, S. 2007. Institutional Entrepreneurship as Embedded Agency: An Introduction to the Special Issue. Organization Studies, 28(07), 957-969.

Gereffi, G., Humphrey, J., \& Sturgeon, T. 2005. The governance of global value chains. Review of International Political Economy, 12(1), 78-104.

Gerschenkron, A. 1962. Economic backwardness in historical perspective: a book of essays. Cambridge, MA: Belknap Press of Harvard University Press.

Gintis, H., Bowles, S., Boyd, R. T., \& Fehr, E. (Eds.). (2005). Moral sentiments and material interests: The foundations of cooperation in economic life (Vol. 6). MIT press.

Grindle, M. S. 2010. Constructing, deconstructing, and reconstructing career civil service systems in Latin America. HKS Faculty Research Working Paper Series, RWP10-025, John F. Kennedy School of Government, Harvard University. 
Groves, T., Hong, Y., McMillan, J., \& Naughton, B. 1995. China's evolving managerial labor market. Journal of Political Economy, 103(4): 873-892.

Guo, Y., Huy, Q. N., \& Xiao, Z. 2017. How middle managers manage the political environment to achieve market goals: Insights from China's state-owned enterprises. Strategic Management Journal, 38(3), 676-696.

Haggard, S. 2018. Developmental States. New York: Cambridge University Press.

Hall, P. 2010. Historical Institutionalism in Rationalist and Sociological Perspective. In Mahoney, J., \& Thelen, K. (eds.), Explaining Institutional Change. Ambiguity, Agency, and Power. Cambridge: Cambridge University Press, pp. 204-224.

Hofman, P. S., Moon, J., \& Wu, B. 2017. Corporate Social Responsibility Under Authoritarian Capitalism: Dynamics and Prospects of State-Led and Society-Driven CSR. Business and Society, 56(5): 651-671.

Horton, S. 2006. The public service ethos in the British civil service: An historical institutional analysis. Public Policy and Administration, 21(1), 32-48.

Hotho, J., \& Saka-Helmhout, A. 2017. In and between societies: Reconnecting comparative institutionalism and organization theory. Organization Studies, 38(5): 647-666.

Hsueh, L.M., Hsu, C.K. \& Perkins, D.H. (Eds.) 2001. Industrialization and the state: The changing role of government in Taiwan's economy, 1945-1998. Cambridge: Harvard Institute for International Development.

Hsueh, R. 2016. State Capitalism, Chinese-Style: Strategic Value of Sectors, Sectoral Characteristics, and Globalization. Governance, 29(1): 85-102.

Huang Y. 2003. Selling China. Harvard University Press: Cambridge, MA.

Huang Y. 2008. Capitalism with Chinese characteristics. Cambridge University Press: New York.

Huang, Y., Xie, E., Li, Y., \& Reddy, K. S. 2017. Does state ownership facilitate outward FDI of Chinese SOEs? Institutional development, market competition, and the logic of interdependence between governments and SOEs. International Business Review, 26(1): 176-188.

Hwang, H., \& Colyvas, J. A. 2011. Problematizing actors and institutions in institutional work. Journal of Management Inquiry, 20, 62-66.

Inoue, C. F., Lazzarini, S. G., \& Musacchio, A. (2013). Leviathan as a minority shareholder: Firm-level implications of state equity purchases. Academy of Management Journal, 56(6), 1775-1801.

Jackson, G. 2010. Actors and Institutions. In G. Morgan, J. Campbell, C. Crouch, O. Pedersen, P. H. Christensen, \& R. Whitley (Eds.), Oxford Handbook of Comparative Institutional Analysis, Oxford: Oxford University Press, pp. 1-25. 
Jensen, Michael C., and William H. Meckling. 1976. Theory of the firm: managerial behavior, agency costs and ownership structure. Journal of Financial Economics 3(4), 305-360.

Jing, R., \& McDermott, E. P. 2013. Transformation of State-owned Enterprises in China: A Strategic Action Model. Management and Organization Review, 9(1): 53-86.

Johns, L., \& Wellhausen, R. L. 2016. Under One Roof: Supply Chains and the Protection of Foreign Investment. American Political Science Review, 110(01): 31-51.

Johnson, C. 1982. MITI and the Japanese Miracle. Stanford, CA: Stanford University Press.

Johnson, S., \& Mitton, T. 2003. Cronyism and capital controls: evidence from Malaysia. Journal of Financial Economics, 67(2): 351-382.

Kalasin, K., Cuervo-Cazurra, A., \& Ramamurti, R. (2019). State ownership and international expansion: The S-curve relationship. Global Strategy Journal, 10(2): 386-418.

Kohli, A. 2004. State-Directed Development. New York: Cambridge University Press.

Kornai, J. 1980. Economics of shortage. Amsterdam: North Holland.

Langlois, R. N. 2003. The vanishing hand: the changing dynamics of industrial capitalism. Industrial and Corporate Change, 12(2): 351-385.

Lardy, N. R. 2014. Markets over Mao: The rise of private business in China. Columbia University Press.

Lawrence, T. B., Hardy, C., \& Phillips, N. 2002. Institutional effects of interorganizational collaboration: The emergence of proto-institutions. Academy of Management Journal, 45(1): 281-290.

Lawrence, T.B. \& Suddaby, R. 2006. Institutions and institutional work In S. Clegg, C. Hardy, T.B. Lawrence, W.R. Nord (Eds.), Handbook of organizational studies (2nd. ed.), London: SAGE, pp. 215-254

Lawrence, T. B., Suddaby, R., \& Leca, B. (Eds.). 2009. Institutional work: Actors and agency in institutional studies of organizations. Cambridge: Cambridge University Press.

Lawrence, T., Suddaby, R., \& Leca, B. 2011. Institutional work: Refocusing institutional studies of organization. Journal of Management Inquiry, 20(1): 52-58.

Lawton, T., Rajwani, T., \& Doh, J. 2013. The antecedents of political capabilities: A study of ownership, cross-border activity and organization at legacy airlines in a deregulatory context. International Business Review, 22(1): 228-242.

Lazzarini, S. G., \& Musacchio, A. (2018). State ownership reinvented? Explaining performance differences between state-owned and private firms. Corporate Governance: An International Review, 26(4), 255-272.

Lester, R. H., Hillman, A., Zardkoohi, A., \& Cannella Jr, A. A. 2008. Former government officials as outside directors: The role of human and social capital. Academy of Management Journal, 51(5), 999-1013. 
Leutert, W. 2018. Firm control: Governing the state-owned economy under Xi Jinping. China Perspectives, 1/2: 27.

Li, M. H., Cui, L., \& Lu, J. 2014. Varieties in state capitalism: Outward FDI strategies of central and local state-owned enterprises from emerging economy countries. Journal of International Business Studies, 45(8): 980-1004.

Li, H., \& Zhang, Y. 2007. The role of managers' political networking and functional experience in new venture performance: Evidence from China's transition economy. Strategic Management Journal, 28(8): 791-804.

Liang, H., Ren, B., \& Sun, S. L. 2015. An anatomy of state control in the globalization of stateowned enterprises. Journal of International Business Studies, 46(2): 223-240.

Lin, L. W., \& Milhaupt, C. J. 2013. We Are the (National) Champions: Understanding the Mechanisms of State Capitalism in China'(2013). Stanford Law Review, 65: 697.

Liu, Y., Zhang, C., \& Jing, R. (2016). Coping with multiple institutional logics: Temporal process of institutional work during the emergence of the one foundation in China. Management and Organization Review, 12(2), 387-416.

Mahoney, J., \& Thelen, K. (eds.). 2010. Explaining Institutional Change. Ambiguity, Agency, and Power. Cambridge: Cambridge University Press.

Markus, S. 2008. Corporate governance as political insurance: firm-level institutional creation in emerging markets and beyond. Socio-Economic Review, 6(1): 69-98.

Markus, S. 2012. Secure property as a bottom-up process: Firms, stakeholders, and predators in weak states. World Politics, 64(2): 242-277.

Markus, S. (2015). Property, predation, and protection. Cambridge: Cambridge University Press.

Marquis, C., \& Qian, C. 2013. Corporate social responsibility reporting in China: Symbol or substance? Organization Science, 25(1): 127-148.

Marquis, C., Zhang, J., \& Zhou, Y. 2011. Regulatory uncertainty and corporate responses to environmental protection in China. California Management Review, 54(1): 39-63.

McDermott, G. 1997. Renegotiating the ties that bind: the limits of privatization in the Czech Republic, in Grabher, G. and Stark, D. (Eds), Restructuring Networks in Post-socialism: Legacies, Linkages and Localities, Oxford University Press, Oxford, pp. 70-106.

McDermott, G. A. (2004). Institutional change and firm creation in east-central Europe: An embedded politics approach. Comparative Political Studies, 37(2), 188-217.

McDermott, G. A. 2007. Politics and the evolution of inter-firm networks: A post-communist lesson. Organization Studies, 28(6): 885-908.

McGaughey, S. L., Kumaraswamy, A., \& Liesch, P. W. 2016. Institutions, entrepreneurship and co-evolution in international business. Journal of World Business, 6(51): 871-881.

McGregor, J. 2012. No ancient wisdom, no followers: The challenges of Chinese authoritarian capitalism. Westport, CT: Easton Studio Press. 
McMahon, D. 2018. China's Great Wall of Debt: Shadow Banks, Ghost Cities, Massive Loans, and the End of the Chinese Miracle. Boston, MA: Houghton Mifflin Harcourt.

Megginson, W. L., \& Netter, J. M. 2001. From State to Market : A Survey of Empirical Studies on Privatization. Journal of Economic Literature, 39(2): 321-389.

Mellahi, K., Frynas, J. G., Sun, P., \& Siegel, D. (2016). A review of the nonmarket strategy literature: Toward a multi-theoretical integration. Journal of Management, 42(1), 143 173.

Micelotta, E. R., \& Washington, M. 2013. Institutions and maintenance: The repair work of Italian professions. Organization Studies, 34(8): 1137-1170.

Mizruchi, M. S. 1992. The Structure of Corporate Political Action: Interfirm Relations and their Consequences. Cambridge, MA: Harvard University Press.

Musacchio, A., Farias, A. M., \& Lazzarini, S. G. (2014). Reinventing state capitalism. Cambridge, MA: Harvard University Press.

Musacchio, A. \& Lazarini, S.G. 2012. Leviathan in business, Varieties of state capitalism and their implications for economic performance, SSRN Working Paper \#20709042.

Musacchio, A., \& Lazzarini, S. G. 2018. State-Owned Enterprises as Multinationals: Theory and Research Directions. In A. Cuervo-Cazurra (Ed.), State-owned multinationals: Governments in global business (pp. 255-276). Palgrave Macmillan.

Musacchio, A., Lazzarini, S. G., \& Aguilera, R. V. 2015. New Varieties of State Capitalism: Strategic and Governance Implications. Academy of Management Perspectives, 29(1): $115-131$.

Nude, W. 2010. Industrial policy: Old and new issues, United Nations WIDER Working Paper, No. 2010/106.

Newman, A. \& Zysman, J., 2006. Transforming politics in the digital era. In: Zysman, A., Newman, A. (Eds.), How Revolutionary was the Digital Revolution? Stanford University Press, Stanford, CA, pp. 391-414.

Noble, G. W. 1998. Collective Action in East Asia: how ruling parties shape industrial policy. Cornell University Press.

Nolan, P. 2001. China and the global business revolution. Basingstoke: Palgrave.

Okhmatovskiy, I. 2010. Performance implications of ties to the government and SOEs: A political embeddedness perspective. Journal of Management Studies, 47(6): 1020-1047.

Oliver, C., \& Holzinger, I. 2008. The effectiveness of strategic political management: A dynamic capabilities framework. Academy of Management Review, 33(2): 496-520.

Pandey, J., \& Varkkey, B. 2020. Impact of religion-based caste system on the dynamics of Indian trade unions: Evidence from two state-owned organizations in North India. Business \& Society, 59(5), 995-1034.

Patrick,H. T. \& Park,Y.-C. 1994. Financial development in Japan, Korea, and Taiwan. New York: Oxford University Press. 
Park, Y. C., \& Patrick, H. (Eds.). 2013. How finance is shaping the economies of China, Japan, and Korea. New York, NY: Columbia University Press.

Peng, M. W. 2003. Institutional transitions and strategic choices. Academy of Management Review, 28(2): 275-296.

Peng, M. W., Bruton, G. D., Stan, C. V., \& Huang, Y. (2016). Theories of the (state-owned) firm. Asia Pacific Journal of Management, 33(2), 293-317.

Pettis, M. 2013. Great rebalancing: Trade, conflict, and perilous road ahead for the world economy, Princeton University Press.

Pierson, P. 2004. Politics in Time. History, Institutions, and Social Analysis. Princeton, NJ: Princeton University Press.

Piore, M. \& Sabel, C. F. 1984 The second industrial divide. New York: Basic Books.

Porter, M. 2008. The Five Competitive Forces that Shape Strategy. Harvard Business Review (January 2008).

Rauch, J. E., \& Evans, P. B. 2000. Bureaucratic structure and bureaucratic performance in less developed countries. Journal of Public Economics, 75(1): 49-71.

Raynard, M., Lu, F., \& Jing, R. Reinventing the State-Owned Enterprise? Negotiating Change during Profound Environmental Upheaval. Academy of Management Journal, forthcoming.

Reinhart, C. 2012. The Return of Financial Repression. CEPR Discussion Papers 8947, C.E.P.R. Discussion Papers, London.

Rodrigues, S. B. \& Dieleman, M. 2018. The internationalization paradox: Untangling dependence in multinational state hybrids. Journal of World Business, 53(1): 39-51.

Rodrik, D. 2004. Industrial Policy for the Twenty-First Century, KSG Working Paper No. RWP04-047, Cambridge MA: Harvard University.

Rodrik, D. 2007. One economics, many recipes: Globalization, institutions and economic growth. Princeton, NJ: Princeton University Press.

Roubini, N., \& Sala-i-Martin, X. 1995. A growth model of inflation, tax evasion, and financial repression. Journal of Monetary Economics, 35(2): 275-301.

Rudy, B. C., Miller, S. R., \& Wang, D. 2016. Revisiting FDI strategies and the flow of firmspecific advantages: A focus on state-owned enterprises. Global Strategy Journal, 6(1): 69-78.

Salamon, L. M., \& Siegfried, J. J. 1977. Economic power and political influence: The impact of industry structure on public policy. American Political Science Review, 71(3): 10261043.

Schneider, B. R. 1992. Politics within the state: elite bureaucrats and industrial policy in authoritarian Brazil. Pittsburgh: University of Pittsburgh Press.

Schmitz, H. 2007. Reducing complexity in the industrial policy debate. Development Policy 
Review, 25(4): 417-428.

Schnyder, G., \& Sallai, D. 2020. Between a rock and a hard place: Internal-and external institutional fit of MNE subsidiary political strategy in contexts of institutional upheaval. Journal of International Management, forthcoming.

Seo, M. G., \& Creed, W. D. 2002. Institutional contradictions, praxis, and institutional change: A dialectical perspective. Academy of Management Review, 27(2), 222-247.

Shankman, N. A. 1999 "Reframing the debate between agency and stakeholder theories of the firm." Journal of Business Ethics, 19(4), 319-334.

Shleifer, A., \& Vishny, R. W. 1998. The grabbing hand. Government pathologies and their cures. Cambridge, MA: Harvard University Press.

Shirley, M., \& Walsh, P. 2000. Public versus private ownership: The current state of the debate. The World Bank.

Situ, H., Tilt, C. A., \& Seet, P.-S. 2018. The influence of the government on corporate environmental reporting in China: An authoritarian capitalism perspective. Business and Society, in press.

Smets, M., \& Jarzabkowski, P. 2013. Reconstructing institutional complexity in practice: A relational model of institutional work and complexity. Human Relations, 66(10): 12791309.

Stark, D. (1996). Recombinant property in East European capitalism. American Journal of Sociology, 101(4): 993-1027.

Stark, D., \& Bruszt, L. 2001. One way or multiple paths: For a comparative sociology of East European capitalism. American Journal of Sociology, 106(4): 1129-1137.

Stark, D., \& Vedres, B. 2012. Political holes in the economy: The business network of partisan firms in Hungary. American Sociological Review, 77(5), 700-722.

Steil, B, Victor, D. G. \& Nelson, R. N. 2002. Technological innovation and economic performance, Princeton, NJ: Princeton University Press.

Streeck, W., \& Thelen, K. 2005. Beyond Continuity. Institutional Change in Advanced Political Economies. Oxford: Oxford University Press.

Sun, P., Mellahi, K., \& Thun, E. 2010. The dynamic value of MNE political embeddedness: The case of the Chinese automobile industry. Journal of International Business Studies, 41(7): 1161-1182.

Swanson, D. L. 2008. Top managers as drivers for corporate social responsibility. In A. Crane, A. McWilliams, D. Matten, J. Moon, \& D. Siegel (Eds.), The Oxford Handbook on Corporate Social Responsibility (pp. 227-245). Oxford, UK: Oxford University Press.

Teng, D., Fuller, D. B., \& Li, C. 2018. Institutional change and corporate governance diversity in China's SOEs. Asia Pacific Business Review, 24(3): 273-293.

Thatcher, M. 2014. From old to new industrial policy via economic regulation. Rivista della Regolazione dei Mercati, 2: 6-22. 
Thelen, K. 2004. How Institutions Evolve. The Political Economy of Skills in Germany, Britain, the United States, and Japan. Cambridge: Cambridge University Press.

Thelen, K. 2012. Varieties of capitalism: Trajectories of liberalization and the new politics of social solidarity. Annual Review of Political Science, 15: 137-159.

Thun, E. 2007. "The Globalization of Production". In Global political economy, 2nd edition, Edited by: Ravenhill, J. 346-371. Oxford: Oxford University Press.

Thornton, P. H., Ocasio, W., \& Lounsbury, M. 2012. The institutional logics perspective: A new approach to culture, structure, and process. Oxford University Press.

Thun, E. 2004. "Industrial policy, Chinese-style: FDI, regulation, and dreams of national champions in the auto sector." Journal of East Asian Studies 4.3: 453-489.

Thynne, I. 2011. Ownership as an instrument of policy and understanding in the public sphere : trends and research agenda. Policy Studies, 32(3), 183-197. https://doi.org/10.1080/01442872.2011.561685

Toninelli, P. A., \& Toninelli, P. M. (Eds.). 2000. The rise and fall of state-owned enterprise in the western world (Vol. 1). Cambridge, UK: Cambridge University Press.

Tonurist, P., \& Karo, E. 2016. State Owned Enterprises As Instruments of Innovation Policy. Annals of Public and Cooperative Economics, 87(4), 623-648. https://doi.org/10.1111/apce.12126

Tooze, A. 2006. The wages of destruction: The making and breaking of the Nazi economy. London: Penguin.

Tracey, P., Phillips, N., \& Jarvis, O. 2011. Bridging institutional entrepreneurship and the creation of new organizational forms: A multilevel model. Organization Science, 22(1), 60-80.

Utterback, J.M. \& Suarez, F.F. 1993. Innovation, competition, and industry structure. Research Policy, 22(1): 1-21.

Van der Wal, Z., De Graaf, G., \& Lasthuizen, K. 2008. What's valued most? Similarities and differences between the organizational values of the public and private sector. Public Administration, 86(2), 465-482.

Vining, A. R., Laurin, C., \& Weimer, D. 2015. The longer-run performance effects of agencification: Theory and evidence from Québec agencies. Journal of Public Policy, 35(2), 193-222. https://doi.org/10.1017/S0143814X14000245

Vogel, S.K. 1996. Freer markets, more rules: Regulatory reform in advanced industrial countries. Ithaca, NY: Cornell University Press.

Voinea, C. L., \& van Kranenburg, H. (2018). Feeling the squeeze: Nonmarket institutional pressures and firm nonmarket strategies. Management International Review, 58(5), 705741.

Wade, R. 1990. Governing the Market. Princeton, NJ: Princeton University Press.

Walter, C. E., \& Howie, F. J. 2011. Red capitalism: The fragile foundation of China's 
extraordinary rise. Singapore: Wiley.

Wang, Y., Jin, P. \& Yang, C. 2016. Relations between the professional backgrounds of independent directors in state-owned enterprises and corporate performance. International Review of Economics \& Finance, 42: 404-411.

Warwick, K. 2013. Beyond industrial policy: Emerging issues and new trends. OECD Science, Technology and Industry Policy Papers, No. 2, OECD Publishing.

Williamson, O.E. 1963. Managerial discretion and business behavior. American Economic Review, 53(5): 1032-1057.

Witt, M. A., \& Redding, G. 2014. China : Authoritarian Capitalism. In M. A. Witt \& G. Redding (Eds.), The Oxford handbook of Asian business systems (pp. 11-32). Oxford: Oxford University Press.

Xin, K. K., \& Pearce, J. L. 1996. Guanxi: Connections as substitutes for formal institutional support. Academy of Management Journal, 39(6): 1641-1658.

Yan, Z. J., Zhu, J. C., Fan, D., \& Kalfadellis, P. 2018. An institutional work view toward the internationalization of emerging market firms. Journal of World Business, 53(5): 682694.

Zara, A., \& Delacour, H. (2020). On the fluidity of institutional change: Complex iinterrelations between multiple types of institutional work during the Serbian transition. Journal of Management Inquiry, 1056492620949688.

Zietsma, C., \& Lawrence, T.B. 2010. Institutional work in the transformation of an organizational field: The interplay of boundary work and practice work. Administrative Science Quarterly 55(2): 189-221.

Zysman, J. 1977. Political strategies for industrial order: State, market, and industry in France. University of California Press. 
TABLES

Table 1. SOE Goals and Interests

\begin{tabular}{|c|c|c|}
\hline \multicolumn{3}{|c|}{ Illustrative SOE Goals and Interests } \\
\hline \multirow[t]{5}{*}{$\begin{array}{l}\text { Commercial } \\
\text { goals }\end{array}$} & \multirow[t]{2}{*}{$\begin{array}{l}\text { Supra-organisational } \\
\text { commercial goals }\end{array}$} & Generating income for the state \\
\hline & & $\begin{array}{l}\text { Maximising returns on investment / } \\
\text { shareholder value }\end{array}$ \\
\hline & \multirow[t]{3}{*}{ SOE-level commercial goals } & Accessing key competitive resources \\
\hline & & Survival \\
\hline & & Profits \\
\hline \multirow{5}{*}{\multicolumn{2}{|c|}{ Strategic policy goals }} & Promote economic development \\
\hline & & Innovation \\
\hline & & $\begin{array}{l}\text { Control of critical strategic infrastructure } \\
\text { and resources }\end{array}$ \\
\hline & & Support during financial distress \\
\hline & & Reduce unemployment \\
\hline \multirow{2}{*}{\multicolumn{2}{|c|}{ Welfare goals }} & Prevent social unrest \\
\hline & & $\begin{array}{l}\text { Provide essential goods and services were } \\
\text { market/private firms fail }\end{array}$ \\
\hline \multicolumn{2}{|l|}{ Political goals } & $\begin{array}{l}\text { Provide rents for key constituencies or } \\
\text { politicians }\end{array}$ \\
\hline \multirow{2}{*}{\multicolumn{2}{|c|}{ TMT's private goals }} & Private benefits of control \\
\hline & & Career advancement \\
\hline
\end{tabular}


Table 2. Propositions: Levels of Operations, Actors and Causal Pathways

\begin{tabular}{|c|c|c|c|}
\hline Propositions & Institutional Level & Actor & Causal Pathway \\
\hline $\begin{array}{l}\text { Financial Repression } \\
\text { (1a): } \\
\text { The greater the } \\
\text { financial repression } \\
\text { in a country, the } \\
\text { greater the } \\
\text { motivation of this } \\
\text { country's SOE TMTs, } \\
\text { for undertaking } I W .\end{array}$ & National Macro & SOE TMT & $\begin{array}{l}\text { Institutions (financial } \\
\text { repression) combined } \\
\text { with Goals to Spur } \\
\text { Motivation (for pro- } \\
\text { institutional maintenance } \\
\text { IW) }\end{array}$ \\
\hline $\begin{array}{l}\text { Financial Repression } \\
\text { (1b): } \\
\text { The greater the } \\
\text { financial repression } \\
\text { in a country, the } \\
\text { more SOEs are } \\
\text { encouraged to grow } \\
\text { in size, thus } \\
\text { accumulating } \\
\text { valuable resources } \\
\text { for IW and } \\
\text { consequently } \\
\text { expanding the scope } \\
\text { for SOE TMTs' IW. }\end{array}$ & National Macro & SOE TMT & $\begin{array}{l}\text { Institutions (financial } \\
\text { repression) lead to } \\
\text { Resource accumulation } \\
\text { that expands Scope }\end{array}$ \\
\hline $\begin{array}{l}\text { Industrial Policy (2a): } \\
\text { The more active an } \\
\text { industrial policy } \\
\text { incorporating SOEs, } \\
\text { the more SOEs have } \\
\text { a stake in the } \\
\text { industrial policy, } \\
\text { heightening SOE } \\
\text { TMTs' motivation to } \\
\text { engage in IW. }\end{array}$ & National Macro & SOE TMT & $\begin{array}{l}\text { Institutions (Industrial } \\
\text { Policy incorporating } \\
\text { SOEs) interacts with } \\
\text { Goals to enhance } \\
\text { Motivation }\end{array}$ \\
\hline $\begin{array}{l}\text { Industrial policy }(2 \mathrm{~b}) \text { : } \\
\text { The more active an } \\
\text { industrial policy } \\
\text { incorporating SOES, }\end{array}$ & National Macro & SOE TMT & $\begin{array}{l}\text { Institutions (Industrial } \\
\text { Policy incorporating } \\
\text { SOEs) enhance Resources } \\
\text { (strategic value and size) }\end{array}$ \\
\hline
\end{tabular}




\begin{tabular}{|c|c|c|c|}
\hline $\begin{array}{l}\text { the higher the } \\
\text { strategic value and/or } \\
\text { increase in size of } \\
\text { SOEs and, therefore, } \\
\text { the more resources } \\
\text { may a SOE draw on } \\
\text { for IW - and, } \\
\text { consequently, the } \\
\text { greater the scope for } \\
\text { SOE TMTS'IW. }\end{array}$ & & & and thus enhance Scope \\
\hline $\begin{array}{l}\text { Industrial Policy (2c): } \\
\text { The more active an } \\
\text { industrial policy } \\
\text { incorporating SOEs, } \\
\text { the more numerous } \\
\text { and the wider the } \\
\text { channels of state- } \\
\text { SOE relations - and, } \\
\text { consequently, the } \\
\text { greater the scope for } \\
\text { SOE TMTS' IW. }\end{array}$ & National Macro & SOE TMT & $\begin{array}{l}\text { Institutions (Industrial } \\
\text { Policy incorporating } \\
\text { SOEs) enhance Scope via } \\
\text { expansion of individual } \\
\text { SOE TMT networks in } \\
\text { the state }\end{array}$ \\
\hline $\begin{array}{l}\text { State Governance of } \\
\text { SOEs (3a): } \\
\text { SOEs governed by a } \\
\text { state agency through } \\
\text { indirect, financial } \\
\text { mechanisms rather } \\
\text { than governed by a } \\
\text { state agency with } \\
\text { direct managerial } \\
\text { control, will have } \\
\text { fewer resources and } \\
\text { hence more limited } \\
\text { scope to engage with } \\
\text { IW. }\end{array}$ & Meso & SOE TMT & $\begin{array}{c}\text { Institutions (State } \\
\text { Governance Structures for } \\
\text { SOEs) via indirect } \\
\text { financial governance } \\
\text { mechanisms restrict the } \\
\text { level of resources which } \\
\text { in turn restricts scope }\end{array}$ \\
\hline $\begin{array}{l}\text { State Governance of } \\
\text { SOEs (3b): } \\
\text { SOEs governed by a } \\
\text { state agency through } \\
\text { indirect, financial } \\
\text { mechanisms rather } \\
\text { than governed by a } \\
\text { state agency with } \\
\text { direct managerial }\end{array}$ & Meso & SOE TMT & $\begin{array}{c}\text { Institutions (State } \\
\text { Governance Structures for } \\
\text { SOEs) via indirect } \\
\text { financial governance } \\
\text { mechanisms provide } \\
\text { isolation from direct } \\
\text { political influence, which } \\
\text { increases autonomy and } \\
\text { SOE TMTs' Scope }\end{array}$ \\
\hline
\end{tabular}




\begin{tabular}{|c|c|c|c|}
\hline $\begin{array}{l}\text { control, will have } \\
\text { greater political } \\
\text { autonomy and hence } \\
\text { scope for IW }\end{array}$ & & & \\
\hline $\begin{array}{l}\text { State Ownership (4a): } \\
\text { The higher the degree } \\
\text { of state ownership, } \\
\text { the more political } \\
\text { resources SOE TMT } \\
\text { may draw on, and the } \\
\text { higher the scope to } \\
\text { engage in IW on the } \\
\text { part of SOE TMTS. }\end{array}$ & Meso & SOE TMT & $\begin{array}{l}\text { Institutions (increasing } \\
\text { State Ownership) leads to } \\
\text { higher Resources } \\
\text { (political) which in turn } \\
\text { expands Scope }\end{array}$ \\
\hline $\begin{array}{l}\text { State Ownership (4b): } \\
\text { There is an inverted } \\
\text { u-shape relationship } \\
\text { between the degrees } \\
\text { of state ownership } \\
\text { and SOEs' scope for } \\
\text { IW: as state } \\
\text { ownership increases, } \\
\text { so will the state } \\
\text { control, leading to } \\
\text { reduced scope for } \\
\text { SOE TMTs'IW, } \\
\text { counterbalancing the } \\
\text { increased scope from } \\
\text { greater political } \\
\text { resources. }\end{array}$ & Meso & SOE TMT & $\begin{array}{l}\text { Counterbalancing the } \\
\text { causal pathway of 4A, } \\
\text { Institutions (increasing } \\
\text { State Ownership) via } \\
\text { increasing control will } \\
\text { decrease Scope so the } \\
\text { increasing political } \\
\text { resources and increasing } \\
\text { state control will result in } \\
\text { an inverted U-shape for } \\
\text { Scope }\end{array}$ \\
\hline $\begin{array}{l}\text { State Ownership (4c): } \\
\text { There is an inverted } \\
\text { u-shape relationship } \\
\text { between the degrees } \\
\text { of state ownership } \\
\text { and SOEs' motivation } \\
\text { to engage in IW: as } \\
\text { state ownership } \\
\text { increases, there will } \\
\text { be greater political } \\
\text { resources and } \\
\text { consequently, greater } \\
\text { scope for IW enhance } \\
\text { SOEs TMTs, } \\
\text { motivation to act }\end{array}$ & Meso & SOE TMT & $\begin{array}{l}\text { Institutions (increasing } \\
\text { State Ownership) via } \\
\text { increasing control lead to } \\
\text { increasing Resources but } \\
\text { also diminishing } \\
\text { Motivation via } \\
\text { diminishing Scope }\end{array}$ \\
\hline
\end{tabular}




\begin{tabular}{|c|c|c|c|}
\hline $\begin{array}{l}\text { (regardless of their } \\
\text { goal divergence / } \\
\text { alignment with those } \\
\text { of state bureaucrats); } \\
\text { with a high degree of } \\
\text { state ownership, } \\
\text { however, reduced } \\
\text { scope for IW } \\
\text { diminishes the } \\
\text { motivation to perform } \\
\text { it. }\end{array}$ & & & \\
\hline $\begin{array}{l}\text { Political } \\
\text { Embeddedness (5a): } \\
\text { The higher the } \\
\text { integration of the } \\
\text { SOE TMT into the } \\
\text { political system, the } \\
\text { higher the political } \\
\text { resources the SOE } \\
\text { may draw upon } \\
\text { ceteris paribus the } \\
\text { more scope for IW by } \\
\text { the SOE TMT. }\end{array}$ & Meso & SOE TMT & $\begin{array}{l}\text { Institutions (integration of } \\
\text { SOE TMT into political } \\
\text { system) will enhance } \\
\text { Scope and in turn enhance } \\
\text { Motivation }\end{array}$ \\
\hline $\begin{array}{l}\text { Political } \\
\text { Embeddedness (5b): } \\
\text { The stronger the } \\
\text { control of the } \\
\text { nomenklatura system, } \\
\text { the lower scope and } \\
\text { thus motivation the } \\
\text { SOE TMT has to } \\
\text { engage in } \mathrm{IW} \text {. }\end{array}$ & Meso & SOE TMT & $\begin{array}{c}\text { Institutions } \\
\text { (Nomenklatura system) } \\
\text { will decrease Scope and } \\
\text { thus decrease Motivation }\end{array}$ \\
\hline $\begin{array}{l}\text { Political } \\
\text { Embeddedness (5c): } \\
\text { The higher the } \\
\text { political skills of } \\
\text { individual members } \\
\text { of the SOE TMT the } \\
\text { more likely the SOE } \\
\text { will garner political } \\
\text { resources and be able } \\
\text { to evade } \\
\text { nomenklatura control }\end{array}$ & Meso & $\begin{array}{l}\text { Individual } \\
\text { members of } \\
\text { SOE TMT }\end{array}$ & $\begin{array}{l}\text { Individuals' political } \\
\text { skills lead to enhanced } \\
\text { Resources and thus } \\
\text { enhanced Scope }\end{array}$ \\
\hline
\end{tabular}




\begin{tabular}{|c|c|c|c|}
\hline $\begin{array}{l}\text { and thereby enhance } \\
\text { the SOE TMT's scope } \\
\text { for IW. }\end{array}$ & & & \\
\hline $\begin{array}{l}\text { Alliances with non- } \\
\text { state actors (6): } \\
\text { The more SOE TMTs } \\
\text { form coalitions with } \\
\text { stakeholders outside } \\
\text { the state sphere, the } \\
\text { higher their scope } \\
\text { and motivation to } \\
\text { perform IW. }\end{array}$ & Meso & $\begin{array}{l}\text { Individual } \\
\text { members of } \\
\text { SOE TMT }\end{array}$ & $\begin{array}{l}\text { TMT alliances with actors } \\
\text { outside the state lead to } \\
\text { enhanced Scope and thus } \\
\text { enhanced Motivation }\end{array}$ \\
\hline $\begin{array}{l}\text { Industry } \\
\text { Characteristics (7a): } \\
\text { To the extent that a } \\
\text { certain period/sector } \\
\text { favors vertically } \\
\text { integrated, scale } \\
\text { economy-based } \\
\text { competition, SOEs } \\
\text { will tend to have } \\
\text { greater strategic } \\
\text { value and larger size, } \\
\text { thus enhancing their } \\
\text { resources and } \\
\text { therefore increasing } \\
\text { SOE TMTs' scope for } \\
\text { enacting IW. }\end{array}$ & Sector & SOE TMT & $\begin{array}{c}\text { Institutions (industry } \\
\text { characteristics) } \\
\text { enhance/decrease } \\
\text { Resources (strategic value } \\
\text { and firm size) and thereby } \\
\text { enhance/decrease Scope }\end{array}$ \\
\hline $\begin{array}{l}\text { Industry } \\
\text { Characteristics (7b) } \\
\text { To the extent that fast } \\
\text { pace of technical } \\
\text { change is prevalent } \\
\text { in a given industry, } \\
\text { leading the state to } \\
\text { deprioritize } \\
\text { established SOEs } \\
\text { thus leading to fewer } \\
\text { resources and } \\
\text { therefore lower scope } \\
\text { for these SOE TMTs } \\
\text { to enact IW. }\end{array}$ & Sector & SOE TMT & $\begin{array}{l}\text { Institutions (fast/slow } \\
\text { technical change) lead to } \\
\text { lower/higher Resources } \\
\text { (SOE strategic value and } \\
\text { financial resources) and } \\
\text { lower/higher Scope for } \\
\text { SOE TMTs }\end{array}$ \\
\hline
\end{tabular}




\section{FIGURES}

Figure 1. Basic causal model

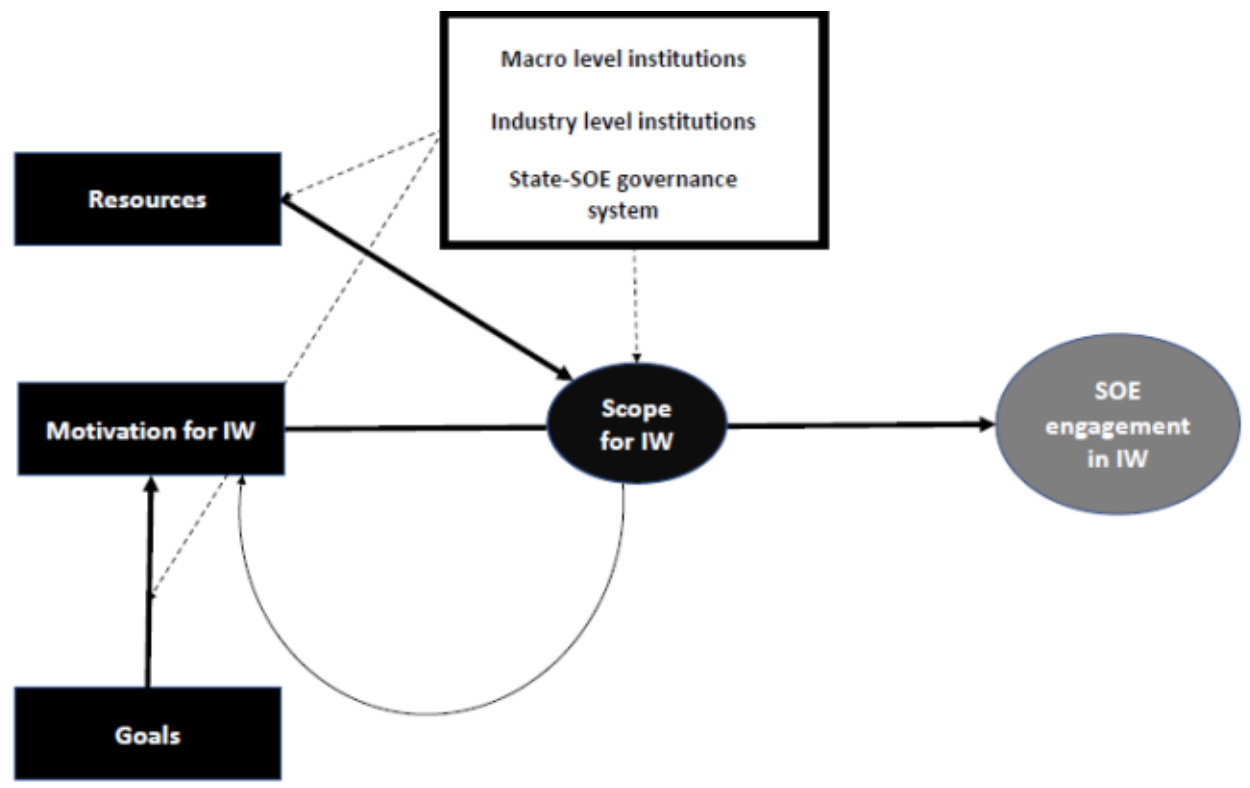

